Provided for non-commercial research and education use. Not for reproduction, distribution or commercial use.

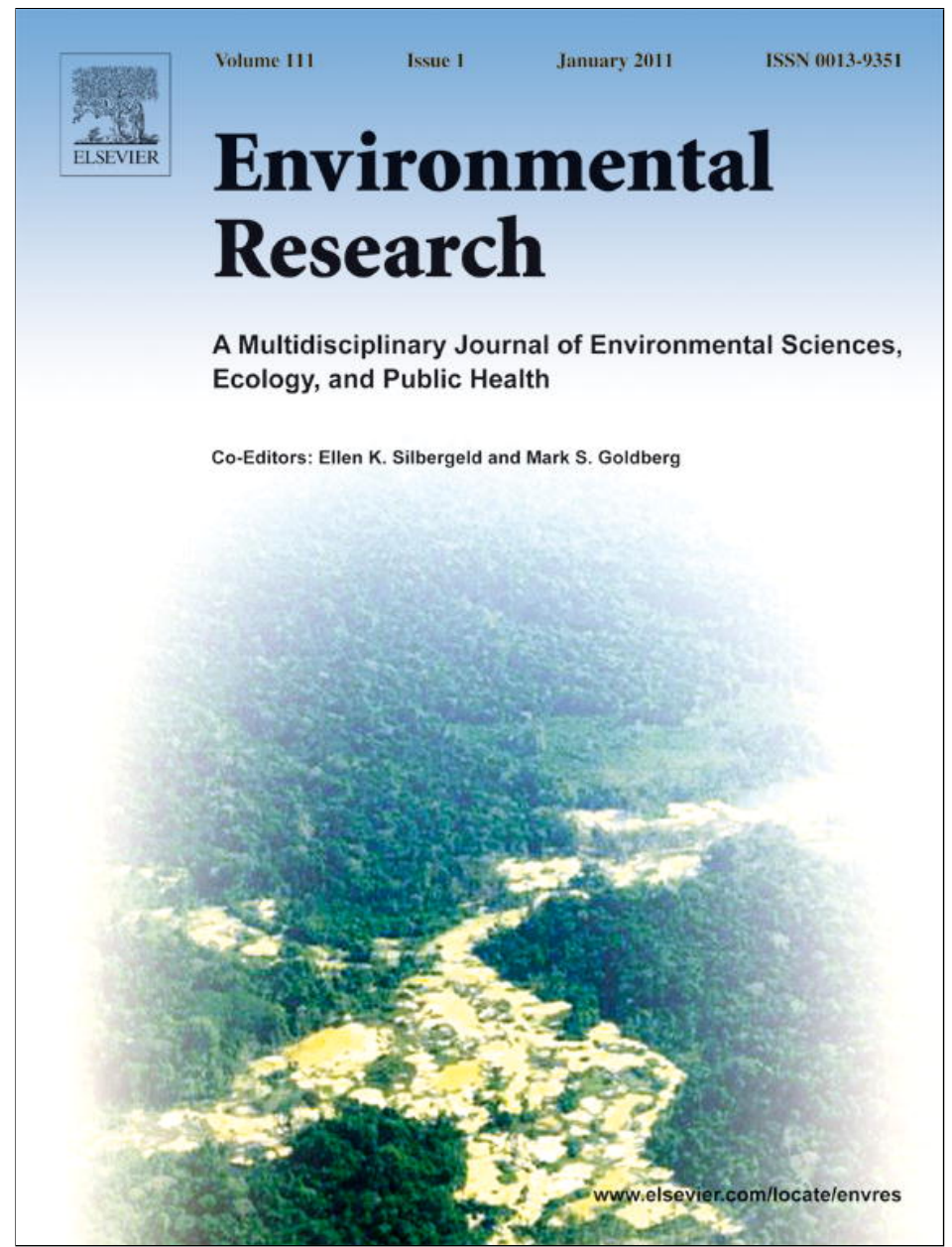

This article appeared in a journal published by Elsevier. The attached copy is furnished to the author for internal non-commercial research and education use, including for instruction at the authors institution and sharing with colleagues.

Other uses, including reproduction and distribution, or selling or licensing copies, or posting to personal, institutional or third party websites are prohibited.

In most cases authors are permitted to post their version of the article (e.g. in Word or Tex form) to their personal website or institutional repository. Authors requiring further information regarding Elsevier's archiving and manuscript policies are encouraged to visit:

http://www.elsevier.com/copyright 


\title{
Assessment of the genotoxic potential of contaminated estuarine sediments in fish peripheral blood: Laboratory versus in situ studies
}

\author{
Pedro M. Costa ${ }^{\mathrm{a}, *}$, Teresa S. Neuparth ${ }^{\mathrm{b}}$, Sandra Caeiro ${ }^{\mathrm{a}, \mathrm{c}}$, Jorge Lobo $^{\mathrm{a}}$, Marta Martins ${ }^{\mathrm{d}}$, Ana M. Ferreira ${ }^{\mathrm{d}}$, \\ Miguel Caetano $^{\mathrm{d}}$, Carlos Vale ${ }^{\mathrm{d}}, \mathrm{T}$. Ángel DelValls ${ }^{\mathrm{e}}$, Maria H. Costa ${ }^{\mathrm{a}}$ \\ a IMAR-Instituto do Mar, Departamento de Ciências e Engenharia do Ambiente, Faculdade de Ciências e Tecnologia da Universidade Nova de Lisboa, 2829-516 Caparica, Portugal \\ b CIIMAR-Centro Interdisciplinar de Investigação Marinha e Ambiental, Laboratório de Toxicologia Ambiental, Universidade do Porto, Rua dos Bragas 289, 4050-123 Porto, Portugal \\ ${ }^{\mathrm{c}}$ Departamento de Ciéncias e Tecnologia, Universidade Aberta, Rua da Escola Politécnica, 141, 1269-001 Lisboa, Portugal \\ d IPIMAR-INRB, Instituto Nacional dos Recursos Biológicos, Avenida de Brasília, 1449-006 Lisboa, Portugal \\ e UNESCO/UNITWIN/WiCop Chair-Departamento de Química Física, Facultad de Ciencias del Mar y Ambientales, Universidad de Cádiz, Polígono río San Pedro s/n, 11510 Puerto Real, \\ Cádiz, Spain
}

\section{A R T I C L E I N F O}

Article history:

Received 25 February 2010

Received in revised form

15 July 2010

Accepted 24 September 2010

Available online 20 October 2010

Keywords:

DNA damage

Lipid peroxidation

Blood cell types

Peripheral blood

Sediment contamination

Solea senegalensis

\begin{abstract}
A B S T R A C T
Juvenile Senegalese soles (Solea senegalensis) were exposed to estuarine sediments through 28-day laboratory and in situ (field) bioassays. The sediments, collected from three distinct sites (a reference plus two contaminated) of the Sado Estuary (W Portugal) were characterized for total organic matter, redox potential, fine fraction and for the levels of metals, polycyclic aromatic hydrocarbons (PAHs) and organochlorines, namely polychlorinated biphenyls (PCBs) and dichloro diphenyl tricholoethane plus its main metabolites (DDTs). Genotoxicity was determined in whole peripheral blood by the single-cell gel electrophoresis (SCGE or "comet") assay and by scoring erythrocytic nuclear abnormalities (ENA). Analysis was complemented with the determination of lipid peroxidation in blood plasma by the thiobarbituric acid reactive substances (TBARS) protocol and cell type sorting. The results showed that exposure to contaminated sediments induced DNA fragmentation and clastogenesis. Still, laboratory exposure to the most contaminated sediment revealed a possible antagonistic effect between metallic and organic contaminants that might have been enhanced by increased bioavailability. The laboratory assay caused a more pronounced increase in ENA whereas a very significant increase in DNA fragmentation was observed in field-tested fish exposed to the reference sediment, which is likely linked to increased lipid peroxidation that probably occurred due to impaired access to food. Influence of natural pathogens was ruled out by unaltered leukocyte counts. The statistical integration of data correlated lipid peroxidation with biological variables such as fish length and weight, whereas the genotoxicity biomarkers were more correlated to sediment contamination. It was demonstrated that laboratory and field bioassays for the risk assessment of sediment contamination may yield different genotoxicity profiles although both provided results that are in overall accordance with sediment contamination levels. While field assays may provide more ecologically relevant data, the multiple environmental variables may produce sufficient background noise to mask the true effects of contamination.
\end{abstract}

(c) 2010 Elsevier Inc. All rights reserved.
Abbreviations: ENA, erythrocytic nuclear abnormalities; DDD, dichloro diphenyl dichloroethane; DDE, dichloro diphenyl dichloroethylene; DDT, dichloro diphenyl thichloroethane; FF, sediment fine fraction; $\mathrm{PAH}$, polycyclic aromatic hydro-

carbon; PCB, polychlorinated biphenyl; PEL, probable effects level guideline; ROS, reactive oxygen species; SCGE, single-cell gel electrophoresis assay; SQG, sediment quality guideline; TBARS, thiobarbituric acid reactive substances; TEL, threshold effects level guideline; TOM, total organic matter; TSB, total DNA strand breakage; VC, variation coefficient

* Corresponding author. Fax: +351212948 554.

E-mail address: pmcosta@fct.unl.pt (P.M. Costa).

\section{Introduction}

Assessment of the genotoxic (mutagenic) potential of environmental contamination has been gaining growing attention within ecological monitoring, human occupational health and fundamental toxicology. One of the factors that account for the importance of determining the genotoxicity of xenobiotics is the relationship between mutagenesis and carcinogenesis. A number of techniques has been employed to study genotoxicity in a broad range of organisms, both in vivo and in vitro, including the micronucleus test and its variations (such as the scoring of total nuclear abnormalities), the sister chromatid assay, DNA-xenobiotic adduct formation and the SCGE, or "comet" assay as it is 
more commonly known, just to quote a few (refer to van der Oost et al., 2003, for a review on genotoxicity and other biomarkers for risk assessment of aquatic environments). Although the usefulness and adequacy of these techniques are seldom under debate, some authors have questioned their application in the monitoring of complex contaminant matrices as natural waters and sediments (e.g. Bombail et al., 2001; Wirzinger et al., 2007). The genotoxic potential of aquatic sediments is recognized as a primary area of concern for environmental toxicologists and, in spite of its inherent difficulties, a great number of tests have been developed to address this issue, using bacteria, invertebrates and fish (Chen and White, 2004). Little research, however, reports the potential differences between laboratory and field (in situ) assays. Different responses and sensitivity to environmental toxicity between the two types of assays with fish and aquatic invertebrates have already been reported and some authors argued that both are important for biomonitoring purposes (Hatch and Burton, 1999; Smolders et al., 2004), including those using flatfish as test organisms, a group of benthic vertebrates recognized as very sensitive to sediment-bound contamination (Johnson et al., 1998).

The two biomarkers, DNA strand breakage (given by the SCGE) and chromosome clastogenesis (assessed by the analysis of ENA); reflect different types of DNA damage. The SCGE assay quantitates DNA fragmentation, single- or double-strand, through the neutral or alkaline versions, respectively, a type of damage that may result from direct DNA chain oxidation, formation of xenobioticDNA adducts and alkali-labile sites. This sort of mutagenesis depends on the action of the cellular DNA-repairing machinery (since single-strand damage may be reversible); hence the genotoxic potential of xenobiotics may be masked by factors affecting cell physiology (see Sarasin, 2003, for a review). Conversely, clastogenesis involves errors during mitosis, causing deleterious mutations, aneuploidies, and other chromosome-level mutations that may be reflected in alterations of nuclear shape and induction of micronuclei. This type of damage is not repairable and is likely to more severely compromise cell and tissue viability. The SCGE assay has been regarded as a more sensitive, expedite and objective tool to assess mutagenesis than more traditional approaches such as sorting ENA. Still, the influence of many confounding factors such as DNA repair capability, subject health and others has been recognized as an important issue when considering this protocol for standard biomonitoring purposes (Moller et al., 2000). Due to the differences between the two biomarkers, the employment of both has become a common procedure for genotoxicity assessment (e.g. Siu et al., 2004; Costa et al., 2008a; Neuparth et al., 2009).

Different contaminants give rise to distinct pathways of mutagenesis although it is believed that reactive oxygen species (ROS) are a common denominator in xenobiotic-induced DNA damage. Organic contaminants such as PAHs (among which is included the well-known carcinogen and teratogen benzo[a]pyrene) are known to induce genotoxicity through the activated PAH forms (e.g. epoxides and quinones) and ROS formed during PAH catabolism by the monooxygenase enzymes of the mitochondrial cytochrome machinery (refer to Miller and Ramos, 2001, for a review). Metals and metalloids, however, have a different, yet poorly understood, mutagenic action. Metalloid mutagenesis and carcinogenesis (such as for arsenic), for instance, have been linked to the formation of ROS (e.g. Liu et al., 2001), although the exact mechanism by which ROS are induced is unclear. It is also suspected that cadmium induces apoptosis and therefore DNA cleavage and clastogenesis, a process also depending on the formation of ROS (Risso-de Faverney et al., 2001). It is believed that metals and metalloids indirectly induce mutagenesis by impairing oxidative metabolism, e.g. by competing with ROSscavenging thiols (reviewed by López-Barea and Gómez-Ariza, 2006). Other authors have found genotoxicity induced by UV light to be enhanced by mercury (Bradfield et al., 2006). The link between genotoxicity and ROS led to many toxicological studies involving genotoxicity and oxidative stress-related biomarkers, such as lipid peroxidation (e.g. Gagné et al., 2008; Moore et al., 2009; Grinevicius et al., 2009). Furthermore, blood cells and plasma are recognized as a convenient vector for analysis since peripheral blood reflects the global health status of the individual. Regarding this issue, fish blood has long gained special attention since fish red blood cells are nucleated and therefore suitable for ENA analysis and obtaining good nucleoids for the SCGE.

Estuaries are major areas of concern regarding environmental contamination. These are, however, complex and labile ecosystems typically subjected to many anthropogenic sources of contamination. The Sado estuary (SW Europe) is no exception to this premise. It consists of a large estuarine basin (second largest in Portugal and one of the largest in Europe) that comprises the urban area of Setúbal, one of the densest heavy-industry conglomerates in the country, mariculture facilities and it also supports important fisheries for the local economy, tourism and part is classified as a natural reserve. The estuary is also subjected to river flows carrying pesticides and fertilizers from the extensive agriculture grounds upstream. For such reasons, recent projects have employed an ecotoxicological approach to assess sediment contamination risk in the area (Caeiro et al., 2005; Neuparth et al., 2005; Costa et al., 2008b), some of which already comprised laboratory bioassays with the benthic fish Solea senegalensis Kaup, 1858 (Pleuronectiformes: Soleidae) (Costa et al., 2008a, 2009a, 2009b), a common fish in the estuary and of importance for local fisheries.

The surveyed sites from the Sado estuary (Fig. 1) were selected according to previous research on the Sado estuary that analyzed sediment physical characteristics and contaminant concentrations (see Caeiro et al., 2005; Costa et al., 2008a). Site R (taken as the reference site) is the farthest from direct pollution sources, especially effluent discharges, whereas sites $C_{1}$ and $C_{2}$ are located

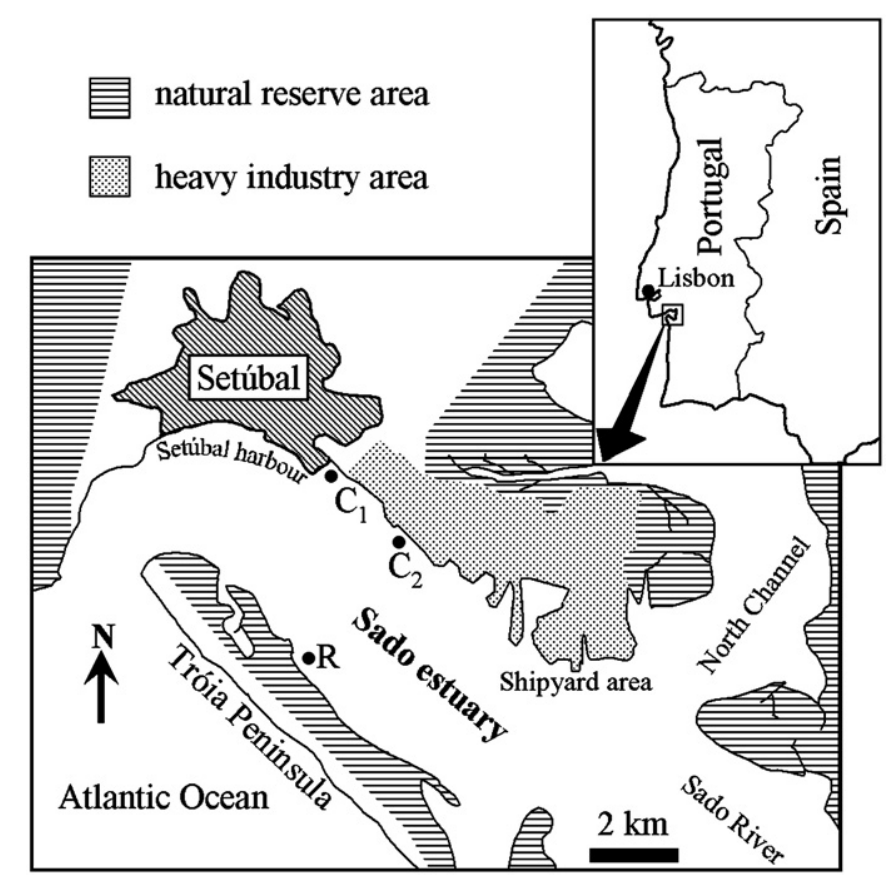

Fig. 1. Map of the study area showing the surveyed sites of the Sado estuary: reference $(R)$ and contaminated $\left(C_{1}\right.$ and $\left.C_{2}\right)$. 
next to the city of Setúbal $t$ and at a newly-built harbor, respectively. These sites are also located just off the city's heavy-industry belt which includes shipyards, a thermoelectrical plant, a paper mill and chemical plants (including fertilizer industries), mineral ore deployment facilities and others, besides being subjected to urban effluents and runoffs from agriculture ground located upstream. Sediments from sites $C_{1}$ and $C_{2}$ have the highest organic and fine fraction loads and are also the most anoxic.

The results from our previous assays performed with $S$. senegalensis showed that even moderate contamination levels have the potential of causing severe chronic lesions and alterations to fish. Also, the interactions organic and metallic contaminant interactions were likely responsible for antagonist and synergistic effects and responses of organisms to contamination. These results have shown that assessing sediment contamination has many constraints and, like noted by other authors, demand caution and a careful selection of bioassay procedures, biomarkers and test organisms (see Chapman et al., 2002, for an overview of the issues concerning the determination of sediment toxicity).

The present works aims at studying the differences and difficulties of determining the genotoxic potential of sedimentbound contamination between laboratory and field (in situ) bioassays. A contribution to the understanding of the interaction effects of distinct classes of metallic and organic contaminants on genotoxicity is also intended, integrating two genotoxicity biomarkers (determination of total DNA strand breakage and chromosomal clastogenesis), blood plasma lipid peroxides and peripheral blood cell counts.

\section{Methods and materials}

\subsection{Experimental procedure}

The sediments (for assays and chemical analysis) were collected from the three sites ( $R, C_{1}$ and $C_{2}$-see Fig. 1) on May 2007 with a Petite Ponar grab. Laboratory and field assays were performed simultaneously during the same period. Juvenile laboratory hatched and reared Senegalese soles (standard length $=61.0+8.4 \mathrm{~mm}$; total wet weight $=3.1+1.6 \mathrm{~g}$ ), all from the same cohort, were used as test subjects. For simplification purposes, exposures to sediments collected from sites $R, C_{1}$ and $C_{2}$ will be throughout referred to as tests $R, C_{1}$ and $C_{2}$.

The laboratory assay was prepared by placing $2 \mathrm{~L}$ of fresh sediments in $15 \mathrm{~L}$ capacity white polyvinyl tanks (with blunt edges) to which were added $10 \mathrm{~L}$ of clean, $0.45 \mu \mathrm{m}$-filtered, seawater. Sediments (providing a surface of $\approx 525 \mathrm{~cm}^{2}$ ) were allowed to settle for $48 \mathrm{~h}$ before the beginning of the assay). A recirculation system was coupled to each tank, water flow being set to prevent sediment resuspension. Aeration was constant. The assays were performed in duplicate, with 20 animals being randomly distributed per tank. The assays were performed under the same conditions of the rearing systems: temperature $=18+1{ }^{\circ} \mathrm{C}$, salinity $=32.1 \pm 0.3$, $\mathrm{pH}=8.0 \pm 0.1$, dissolved oxygen $=56.5 \pm 0.2 \%$ and total ammonia was restrained within $1.6 \pm 0.6 \mathrm{mg} \mathrm{L}^{-1}$. Water parameters were monitored weekly and a $25 \%$ water change was done at the same interval to ensure their constancy with minimal removal of contaminants and suspended matter. Fish were fed once a day with commercial M2 grade fish pellets (from Sorgal).

The field assay was performed with submerged cages (at a depth between 7 and $10 \mathrm{~m}$ ), placed over the bottom using scuba equipment, ensuring that fish were in direct contact with the sediments. The cages $(90 \times 90 \times 30 \mathrm{~cm})$, lined with a $5 \mathrm{~mm}$ plastic mesh, were divided into two equal-sized compartments (replicates), each allocating 20 randomly selected animals.

Both types of assays had the duration of 28 days, with sampling times scheduled at days $0\left(T_{0}\right), 14\left(T_{14}\right)$ and $28\left(T_{28}\right)$. Five animals per replicate (10 at the total) were retrieved from the cages (and transported alive to the laboratory in separate $20 \mathrm{~L}$ vessels per replicate) or test tanks at $T_{14}$ and $T_{28}$, measured for total wet weight ( $\left.w w_{\mathrm{t}}\right)$ and standard length $\left(L_{\mathrm{s}}\right)$. Blood was collected just above the lateral line, from each individual, with a hypodermic syringe previously washed with an EDTA solution to prevent clotting. Animals sampled at $T_{0}$ consisted of 12 fish collected directly from the rearing tanks and where handled as aforementioned.

\subsection{Sediment analyses}

Sediment element contaminants, namely the non-metal selenium (Se), the metalloid arsenic (As) and the metals cadmium (Cd), cobalt $(\mathrm{Co})$, chromium $(\mathrm{Cr})$, copper $(\mathrm{Cu})$, manganese $(\mathrm{Mn})$, nickel $(\mathrm{Ni})$, lead $(\mathrm{Pb})$ and zinc $(\mathrm{Zn})$ were determined in dry sediment samples mineralized with a mixture of acids ( $6 \mathrm{~mL} \mathrm{HF} 40 \% \mathrm{v} / \mathrm{v}$ to which was added $1 \mathrm{~mL}$ of the mixture $36 \% \mathrm{HCl}$ plus $60 \% \mathrm{HNO}_{3} 3: 1 \mathrm{v} / \mathrm{v}$ ) in closed Teflon vials, according to Caetano et al. (2007). Element quantification was achieved by inductively coupled plasma mass spectrometry (ICP-MS) using a Thermo Elemental X-Series equipment. Total mercury (Hg) was determined in dried sediment samples by atomic absorption spectrometry (AAS) after pyrolysis of the samples at $750{ }^{\circ} \mathrm{C}$ in an oxygen atmosphere in a combustion tube attached to an AMA-254 mercury analyzer (Leco), according to Costley et al. (2000). The reference sediments MESS-2and PACS-2 (National Research Council, Canada) and MAG-1

(US Geological Survey, USA) were analyzed by these procedures to validate the methods and the values were found within the certified range.

Sediment PAH concentrations were determined from dry samples spiked with surrogate standards (from Supelco) and Soxhlet-extracted with an acetone+hexane $(1: 1 \mathrm{v} / \mathrm{v})$ mixture. Compounds were quantified by gas chromatography-mass spectrometry (GC-MS) as described by Martins et al. (2008), using a Finnigan GCQ system. A total of seventeen 3- to 6-ring PAHs were quantified. Organochlorines (18 PCB congeners and DDTs, namely $p p^{\prime} \mathrm{DDT}$ plus the $p p^{\prime} \mathrm{DDD}$ and $p p^{\prime} \mathrm{DDE}$ metabolites) were quantified from dried sediment samples Soxhlet-extracted with $n$-hexane. Extracts were fractioned in a chromatographic column and compounds quantified by GC with an electron capture detector (Ferreira et al., 2003) using a Hewlett-Packard 6890 apparatus. Validation of the organic contaminant determination procedure was obtained by analysis of the SRM 1941b reference sediment (National Institute of Standards and Technology, USA) and the obtained values were observed to be within the certified range.

Sediment total organic matter (TOM) and was determined by organic carbon loss-on-ignition (LOI) at $500{ }^{\circ} \mathrm{C}$. Fine fraction (FF), particle size $<63 \mu \mathrm{m}$, was determined by hydraulic sieving after disaggregation with pyrophosphate. Both results are expressed as percentage of total sediment dry weight (dw). Sediment redox potential (Eh) was measured immediately after collection with an Orion $20 \mathrm{~A}$ apparatus equipped with a $\mathrm{H} 3131$ platinum electrode with an $\mathrm{Ag} / \mathrm{AgCl}$ reference electrode.

\subsection{Analysis of the potential sediment contamination impact}

The sediments' potential for causing adverse biological effects of the tested sediments was evaluated by calculating the PEL quotient (PEL-Q) based on the published guideline values for coastal waters, namely the threshold effects level $(T E L)$ and the probable effects level (PEL), according to Macdonald et al. (1996). The $P E L-Q$ indice was calculated for each contaminant, according to the formula described by Long and MacDonald (1998):

$P E L-Q_{i}=\frac{C_{i}}{P E L}$

Being PEL the guideline value for the contaminant $i$ and $C_{i}$ the measured concentration of the same contaminant. The sediment quality guideline quotient indice $(S Q G-Q)$, developed to compare sites affected by contaminant mixtures, was calculated for each sediment according to Long and MacDonald (1998) as

$S Q G-Q=\frac{\sum_{i=1}^{n} P E L-Q_{i}}{n}$

where $n$ is the total number of contaminants under analysis for which sediment quality guidelines are available. The three stations were sorted according to their sediment contamination potential for causing adverse biological effects: $S Q G-Q<0.1$ - unimpacted; $0.1 \leq S Q G-Q<1$-moderately impacted; $S Q G-Q \geq 1$ highly impacted (MacDonald et al., 2004).

\subsection{Determination of genotoxicity}

The alkaline single-cell gel electrophoresis assay was employed in wholeblood according to Singh et al. (1988) and as previously tested and described for this species by Costa et al. (2008a). Analysis was run immediately after blood collection to ensure maximum cell viability. All steps onward were performed under dim light to avoid accessory DNA strand breakage. The room temperature was held constant at $\approx 20^{\circ} \mathrm{C}$ and all solutions were used cold $\left(\approx 4{ }^{\circ} \mathrm{C}\right)$ to avoid DNA damage and agarose lifting from the slides. Blood cell suspensions were obtained by diluting $(1: 100)$ blood aliquots in cold PBS (phosphate-buffered saline), $\mathrm{pH} 7.4$ with $0.7 \% \mathrm{NaCl}$. Aliquots of cell suspensions were then diluted in liquid $\left(\approx 37^{\circ} \mathrm{C}\right) 1 \% \mathrm{w} / \mathrm{v}$ low-melting point agarose (Sigma) and placed $(2 \times 75 \mu \mathrm{L})$ on microscopy slides previously coated with dry high melting point agarose. After cell lysis for $1 \mathrm{~h}$ (in the dark, at $4{ }^{\circ} \mathrm{C}$ ) in a solution containing $2.64 \% \mathrm{w} / \mathrm{v} \mathrm{NaCl}, 3.72 \%$ $\mathrm{w} / \mathrm{v}$ EDTA (w/v) and $5 \mathrm{mM}$ TRIS to which was added $10 \% \mathrm{v} / \mathrm{v}$ DMSO and $1 \% \mathrm{v} / \mathrm{v}$ Triton-X 100 just before use, slides were placed in cold alkaline electrophoresis solution $(0.1 \mu \mathrm{M}$ EDTA, $0.3 \mathrm{M} \mathrm{NaOH})$ to promote DNA unwinding and high expression of alkali-labile sites. Electrophoresis was run in the dark and in cold for $30 \mathrm{~min}$ at $25 \mathrm{~V}$ using a Bio-Rad Sub-Cell 96 apparatus. Slides were afterwards neutralized in Tris-HCl buffer ( $\mathrm{pH} 7.5$ ). Slides were stained with ethidium bromide for analysis. Approximately 100 cells were scores per slide, the \% of DNA in the 
comets' tail being used as a direct measure of total (single and double strand) DNA strand-breakage (Lee and Steinert, 2003). Image analysis was performed with the software CometScore 1.5 (TriTek).

Erythrocyte nuclear clastogenesis was determined by scoring the percentage of mature red blood cells (RBCs) exhibiting nuclear abnormalities (ENA). The analysis was performed on methanol-fixed blood smears (15 min), stained with $0.1 \mathrm{~g} \mathrm{~L}^{-1}$ acridine orange fluorochrome, as described by Costa and Costa (2007). Approximately 1000 mature erythrocytes were scored per slide.

For both analyses, a Leica DMLB model microscope adapted for epifluorescence and equipped with a EL6000 light source for mercury short-arc reflector lamps was used. I3 and N2.1 filters were employed for acridine orange- and ethidium bromide-stained slides, respectively. All equipments were obtained from Leica Microsystems. Total DNA strand breakage and ENA data are expressed as variation coefficients $\left(V C_{\mathrm{TSB}}\right.$ and $V C_{\mathrm{ENA}}$, respectively) relatively to $T_{0}$ animals.

\subsection{Discrimination of blood cell types}

The relative proportions of leukocytes, thrombocytes and immature erythrocytes were determined in acridine orange-stained blood smears, prepared as described in the previous section. At least 1000 intact cells were scored per slide. Results are given as percentage of each cell class relatively to the total number of cells counted.

\subsection{Plasma lipid peroxides assay}

The determination of blood plasma lipid peroxides was adapted from the thiobarbituric acid reactive substances (TBARS) protocol developed by Uchiyama and Mihara (1978). In brief: blood samples were centrifuged (10 min, $10000 \mathrm{~g}$ ) to separate the plasma from the blood cells and $5 \mu \mathrm{L}$ of plasma were diluted in $45 \mu \mathrm{L}$ PBS (pH 7.4, with $0.7 \% \mathrm{NaCl}$ ) to which was added $100 \mu \mathrm{L}$ ice-cold trichloroacetic acid $(10 \% \mathrm{~m} / \mathrm{v})$. Samples were afterwards incubated at $\approx 4{ }^{\circ} \mathrm{C}$ for $15 \mathrm{~min}$ to allow protein to precipitate. Following a $15 \mathrm{~min}$ centrifugation $(2200 \mathrm{~g}), 100 \mu \mathrm{L}$ of the clear supernatant was taken and added $100 \mu \mathrm{L} 0.1 \% \mathrm{~m} / \mathrm{v}$ thiobarbituric acid (diluted in MQ-grade ultrapure water by adding $10 \mathrm{M} \mathrm{NaOH}$ ). The samples were then incubated for $15 \mathrm{~min}$ on boiling water. The absorbance of the reddish pigment $(530 \mathrm{~nm})$ was measured using a Benchmark Microplate Reader (Bio-Rad). Ninety six-well plates were used, each well containing $150 \mu \mathrm{L}$ of the reaction, blanks or standards. Quantification was performed through an eight-point calibration curve (0-300 nM TBARS) using malondialdehyde bis(dimethylacetal) from Merck as standard. Preliminary set-up TBARS assays confirmed that residua hemoglobin produces false MDA-equivalent positives, which was observed to be highly relevant when separating plasma from the small blood samples obtained from the fish (e.g. see Gilbert et al., 1984 concerning the interference of haemolysates on TBARS test). For such reason, a correction factor was introduced according to the relative proportion of residual hemoglobin present in plasma samples, determined by the cyanmethemoglobin method (van Kampen and Zijlstra, 1961). Final results are expressed as plasma lipid peroxide variation coefficients relatively to $T_{0}$-sampled fish ( $V C_{\text {TBARS }}$ ).

\subsection{Statistical analyses}

Following the invalidation of the homogeneity of variances assumption (through the Levene's test), non-parametric analyses were done using the Kruskall-Wallis ANOVA by ranks $H$ statistic for overall differences, the MannWhitney $U$-test for pairwise comparisons and the Spearman's rank-order correlation $\rho$. Correlation-based principal component analysis (PCA) was employed to rank the variables that contribute the most to explain the variation within laboratory and field assays. Discriminant analysis was used to assess the divergence between both types of assays. All statistics were computed using Statistica (Statsoft)

\section{Results}

\subsection{Mortality}

A distinct pattern of mortality was observed between the two types of assays. In the laboratory assays, exposure to sediment $C_{2}$ yielded the highest level of mortality after the 28 days of the assay (14 out of 40 individuals), followed by exposed to sediment $R$ and $C_{1}$ (7/40 and 5/40, respectively). With respect to the field assay, exposure to sediment $\mathrm{R}$ (the reference sediment) caused the highest mortality at the end of the experiment (13/40) while only 5/40 fish were lost for both tests $C_{1}$ and $C_{2}$.

\subsection{Sediment characterization}

The three sediments revealed distinct physical characteristics and different levels of contamination (Table 1). The sediment from site $C_{1}$ was found to be the most contaminated by metals, although presenting PAH levels close to those observed for sediment $\mathrm{C}_{2}$, the most contaminated by 4 - to 6-ring compounds, except benzo(e)pyrene. The reference sediment (from site $\mathrm{R}$ ) was found to be unimpacted, presenting the lowest global sediment quality guideline quotient $\left(S Q G-Q_{t}\right)$. Sediments $C_{1}$ and $C_{2}$ were, however, found to be globally moderately impacted by contaminants (SQG- $Q_{t}=0.33$ and 0.28 , respectively). Copper is the only contaminant reaching the TEL guideline value in sediment from site $\mathrm{R}$, confirming its overall low contamination. On the other hand, PEL levels are reached for $\mathrm{Cu}, \mathrm{Zn}$ and fluoranthene in sediments from site $\mathrm{C}_{1}$ and total $\mathrm{Hg}$ (organic plus inorganic species) and fluoranthene in sediments from site $C_{2}$, hence the major contributors to the $S Q G-Q$ levels observed. The sediment from site $C_{1}$ had the highest content in TOM and FF, followed by $\mathrm{C}_{2}$. As expected, a linear relationship was observed between FF and TOM $\left(r^{2}=0.98\right)$. The most anoxic sediment was found to be from site $C_{2}$ (with the lowest Eh), followed by $C_{1}$. The phenanthrene/anthracene and fluoranthene/pyrene ratios were found to be $>1$ and $<10$, respectively, for all sediments, indicating the PAHs are essentially of pyrolytic nature (combustion-derived) and not petrogenic (Budzinski et al., 1997).

\subsection{Genotoxicity}

Total DNA fragmentation analyzed by the SCGE assay yielded distinct TSB levels between laboratory- and field-exposed fish. Only in laboratory-tested fish collected at $T_{14}$ and exposed to the reference sediment $(R)$ no significant induction of total DNA strand breakage was observed relatively to $T_{0}$ fish (Mann-Whitney $U, P>0.05$ ). All other tests caused an increase in TSB, ranging between 1.5 -fold (in laboratory-exposure to the reference sediment at $T_{28}$ ) and 5.8-fold (in fish exposed to the $C_{2}$ sediment, in laboratory, collected at $T_{28}$ ), relatively to $T_{0}$ animals (Fig. 2). Laboratory exposure to sediment $C_{2}$ was the responsible for the highest induction of TSB, with significant differences being found from all other tests, at $T_{14}$ and $T_{28}$ (Mann-Whitney $U$, $P<0.01$ ). Laboratory exposure to sediment $C_{1}$ derived a significant increase in $V C_{\mathrm{TSB}}$ from $T_{14}$ to $T_{28}$, which was not observed for the other tests. Exposure to sediment $C_{1}$ caused the highest induction of TSB in the field assay, statistically different from exposures to sediments $R$ and $C_{2}$ at $T_{14}$ and only from exposures to sediment $C_{2}$ at $T_{28}$ (Mann-Whitney $U, P<0.01$ ), caused by a significant increase in TSB in R-tested fish from $T_{14}$ to $T_{28}$ (Mann-Whitney $U, P<0.01$ ). No differences were found between replicates (Kruskall-Wallis $H, P>0.05$ ).

In accordance to what has been previously described for the species (Costa et al., 2008a), nuclear budding and fragmentation were the most recurrent ENA observed (Fig. 3b-e). Analysis of ENA depicted significant differences between laboratory- and field-exposed fish (Kruskall-Wallis $H, P<0.01$ ) since, even though a similar pattern was observed regarding the induction of ENA relatively to $T_{0}$, the field-exposed fish exhibited lower frequencies of mature erythrocytes with evidence of clastogenesis (Fig. 4). Laboratory exposure to sediment $C_{2}$ induced more ENA than the other tests (Mann-Whitney $U, P<0.01$ ). Regarding the field assay, tests $C_{1}$ and $C_{2}$ did not exhibit significant differences between each other at either $T_{14}$ or $T_{28}$ (Mann-Whitney $U, P=0.14$ and 0.43 , respectively), although both significantly induced clastogenesis comparatively to exposure to the reference sediment at both $T_{14}$ and $T_{28}$ (Mann-Whitney $U, P<0.05$ ). Still, no increase was 
Table 1

Physico-chemical characterization and contamination profiles of the sediments collected from the three study sites (R, $C_{1}$ and $C_{2}$ ). The $T E L$ and $P E L$ sediment quality guidelines were obtained from Macdonald et al. (1996).

\begin{tabular}{|c|c|c|c|c|c|c|c|c|}
\hline \multirow{5}{*}{ Contaminant } & & & Site & $\mathbf{R}$ & $\mathrm{C}_{1}$ & $\mathrm{C}_{2}$ & \multirow[b]{4}{*}{ SQGS } & \\
\hline & & & TOM (FF) & 2.3 & 10.2 & 7.2 & & \\
\hline & & & $\mathrm{FF}(\%)$ & 22.5 & 95.6 & 75.8 & & \\
\hline & & & \multirow[b]{2}{*}{ Eh $(\mathrm{mV})$} & \multirow[b]{2}{*}{-140} & \multirow[b]{2}{*}{-300} & \multirow[b]{2}{*}{-312} & & \\
\hline & & & & & & & $T E L$ & $P E L$ \\
\hline \multirow{12}{*}{\multicolumn{2}{|c|}{$\begin{array}{l}\text { Metallic/other } \\
\qquad\left(\mu \mathrm{g} \mathrm{g}^{-1} \text { sediment } \mathrm{dw}\right)\end{array}$}} & Non-metal & $\mathrm{Se}$ & $0.27 \pm 0.01$ & $1.21 \pm 0.02$ & $0.80 \pm 0.02$ & $N G$ & $N G$ \\
\hline & & Metalloid & As & $5.20 \pm 0.10$ & $23.98 \pm 0.48^{*}$ & $20.69 \pm 0.41^{*}$ & 7.24 & 41.6 \\
\hline & & Metal & $\mathrm{Cd}$ & $0.06 \pm 0.00$ & $0.26 \pm 0.01$ & $0.29 \pm 0.01$ & 0.68 & 4.21 \\
\hline & & & Co & $3.37 \pm 0.07$ & $13.94 \pm 0.28$ & $9.43 \pm 0.19$ & $N G$ & $N G$ \\
\hline & & & $\mathrm{Cr}$ & $18.14 \pm 0.36$ & $80.73 \pm 1.61^{*}$ & $51.70 \pm 1.03$ & 52.3 & 160 \\
\hline & & & $\mathrm{Cu}$ & $28.20 \pm 0.56^{*}$ & $172.72 \pm 3.45^{* *}$ & $95.31 \pm 1.91^{*}$ & 18.7 & 108 \\
\hline & & & $\mathrm{Hg}$ & $0.11 \pm 0.00$ & $0.69 \pm 0.01^{*}$ & $0.71 \pm 0.01^{* *}$ & 0.13 & 0.7 \\
\hline & & & Mn & $100.75 \pm 2.01$ & $464.34 \pm 9.29$ & $362.47 \pm 7.25$ & $N G$ & $N G$ \\
\hline & & & $\mathrm{Ni}$ & $7.31 \pm 0.15$ & $33.30 \pm 0.67^{*}$ & $20.49 \pm 0.41^{*}$ & 15.9 & 42.8 \\
\hline & & & $\mathrm{Pb}$ & $18.57 \pm 0.37$ & $55.19 \pm 1.10^{*}$ & $43.76 \pm 0.88^{*}$ & 30.2 & 112 \\
\hline & & & $\mathrm{Zn}$ & $72.29 \pm 1.45$ & $364.83 \pm 7.30^{* *}$ & $269.31 \pm 5.39^{*}$ & 124 & 271 \\
\hline & & & SQG-Q Metallic & 0.16 & 0.79 & 0.58 & & \\
\hline \multirow{46}{*}{$\begin{array}{l}\text { Organic } \\
\qquad\left(\mathrm{ngg}^{-1} \text { sediment dw }\right)\end{array}$} & \multirow[t]{18}{*}{$\mathrm{PAH}$} & 3-ring & acenaphthylene & $0.79 \pm 0.13$ & $2.38 \pm 0.40$ & $2.18 \pm 0.37$ & 5.87 & 128 \\
\hline & & & acenaphthene & $0.73 \pm 0.12$ & $12.25 \pm 2.08^{*}$ & $7.83 \pm 1.33^{*}$ & 6.71 & 88.9 \\
\hline & & & fluorene & $1.19 \pm 0.20$ & $15.33 \pm 2.61$ & $9.95 \pm 1.69$ & 21.2 & 144 \\
\hline & & & phenanthrene & $10.28 \pm 1.75$ & $63.87 \pm 10.86$ & $59.91 \pm 10.18$ & 86.7 & 544 \\
\hline & & & anthracene & $2.30 \pm 0.39$ & $21.00 \pm 3.57$ & $20.84 \pm 3.54$ & 46.9 & 245 \\
\hline & & 4-ring & fluoranthene & $23.34 \pm 3.97$ & $315.71 \pm 53.67^{*}$ & $345.24 \pm 58.69^{*}$ & 113 & 1494 \\
\hline & & & pyrene & $21.51 \pm 3.66$ & $263.18 \pm 44.74^{*}$ & $286.33 \pm 48.68^{*}$ & 153 & 1398 \\
\hline & & & benzo(a)anthracene & $3.70 \pm 0.63$ & $81.25 \pm 13.81^{*}$ & $93.99 \pm 15.98^{*}$ & 74.8 & 693 \\
\hline & & & chrysene & $2.35 \pm 0.40$ & $41.06 \pm 6.98$ & $46.68 \pm 7.94$ & 108 & 846 \\
\hline & & 5-ring & benzo(b)fluoranthene & $5.71 \pm 0.97$ & $98.00 \pm 16.66$ & $115.97 \pm 19.72$ & $N G$ & $N G$ \\
\hline & & & benzo(k)fluoranthene & $2.22 \pm 0.38$ & $30.76 \pm 5.23$ & $44.82 \pm 7.62$ & $N G$ & $N G$ \\
\hline & & & benzo(e)pyrene & $4.80 \pm 0.82$ & $74.95 \pm 12.74$ & $8.96 \pm 1.52$ & $N G$ & $N G$ \\
\hline & & & benzo(a)pyrene & $5.42 \pm 0.92$ & $101.86 \pm 17.32^{*}$ & $126.7 \overline{\overline{6}} \pm 21.55^{*}$ & 88.8 & 763 \\
\hline & & & perylene & $7.83 \pm 1.33$ & $96.29 \pm 16.37$ & $113.47 \pm 19.29$ & $N G$ & $N G$ \\
\hline & & & dibenzo(a.h)anthracene & $0.66 \pm 0.11$ & $13.32 \pm 2.26^{*}$ & $13.93 \pm 2.37^{*}$ & 6.22 & 135 \\
\hline & & 6-ring & indeno(1.2.3-cd)pyrene & $5.06 \pm 0.86$ & $82.06 \pm 13.95$ & $95.00 \pm 16.15$ & $N G$ & $N G$ \\
\hline & & & benzo(g.h.I)perylene & $3.91 \pm 0.66$ & $51.93 \pm 8.83$ & $55.85 \pm 9.49$ & $N G$ & $N G$ \\
\hline & & & $\begin{array}{l}\text { TPAH } \\
\text { SQG-Q PAHs }\end{array}$ & $\begin{array}{l}101.80 \\
0.01\end{array}$ & $\begin{array}{l}1365.20 \pm 232.08 \\
0.11\end{array}$ & $\begin{array}{l}1447.71 \pm 246.11 \\
0.12\end{array}$ & 1684 & 16770 \\
\hline & PCB & Trichlorinated & 18 & $<$ d.l. & $0.27 \pm 0.05$ & $0.42 \pm 0.07$ & $N G$ & $N G$ \\
\hline & & & 26 & $<$ d.l. & $1.80 \pm 0.31$ & $1.99 \pm 0.34$ & $N G$ & $N G$ \\
\hline & & & 31 & $0.05 \pm 0.01$ & $0.26 \pm 0.04$ & $0.34 \pm 0.06$ & NG & $N G$ \\
\hline & & Tetrachlorinated & 44 & $0.03 \pm 0.01$ & $0.17 \pm 0.03$ & $0.40 \pm 0.07$ & $N G$ & $N G$ \\
\hline & & & 49 & $<$ d.l. & $0.13 \pm 0.02$ & $0.24 \pm 0.04$ & $N G$ & $N G$ \\
\hline & & & 52 & $<$ d.l. & $0.10 \pm 0.02$ & $0.44 \pm 0.07$ & $N G$ & $N G$ \\
\hline & & Pentachlorinated & 101 & $0.03 \pm 0.01$ & $0.25 \pm 0.04$ & $0.46 \pm 0.08$ & NG & $N G$ \\
\hline & & & 105 & $<$ d.l. & $0.26 \pm 0.04$ & $0.39 \pm 0.07$ & $N G$ & $N G$ \\
\hline & & & 118 & $<$ d.l. & $0.55 \pm 0.09$ & $0.77 \pm 0.13$ & $N G$ & $N G$ \\
\hline & & Hexachlorinated & 128 & $<$ d.l. & $0.26 \pm 0.04$ & $0.48 \pm 0.08$ & $N G$ & $N G$ \\
\hline & & & 138 & $0.14 \pm 0.02$ & $0.71 \pm 0.12$ & $1.08 \pm 0.18$ & NG & $N G$ \\
\hline & & & 149 & $0.08 \pm 0.01$ & $0.05 \pm 0.01$ & $0.30 \pm 0.05$ & $N G$ & $N G$ \\
\hline & & & 151 & $0.06 \pm 0.01$ & $0.77 \pm 0.13$ & $1.14 \pm 0.19$ & $N G$ & $N G$ \\
\hline & & & 153 & $0.13 \pm 0.02$ & $0.98 \pm 0.17$ & $1.28 \pm 0.22$ & $N G$ & $N G$ \\
\hline & & Heptachlorinated & 170 & $0.07 \pm 0.01$ & $0.20 \pm 0.03$ & $0.25 \pm 0.04$ & $N G$ & $N G$ \\
\hline & & & 180 & $0.05 \pm 0.01$ & $0.73 \pm 0.12$ & $1.22 \pm 0.21$ & $N G$ & $N G$ \\
\hline & & & 187 & $0.14 \pm 0.02$ & $0.29 \pm 0.05$ & $0.47 \pm 0.08$ & $N G$ & $N G$ \\
\hline & & & 194 & $0.01 \pm 0.00$ & $0.12 \pm 0.02$ & $0.29 \pm 0.05$ & $N G$ & $N G$ \\
\hline & & & tPCB & $0.80 \pm 0.14$ & $7.91 \pm 1.34$ & $11.97 \pm 2.04$ & 21.6 & 189 \\
\hline & & & $S Q G-Q P C B S$ & 0.00 & 0.04 & 0.06 & & \\
\hline & DDT & & $p p^{\prime} \mathrm{DDD}$ & $<$ d.l. & $0.37 \pm 0.06$ & $0.71 \pm 0.12$ & 1.22 & 7.81 \\
\hline & & & $p p^{\prime} \mathrm{DDE}$ & $<$ d.l. & $<$ d.l. & $0.59 \pm 0.10$ & 2.07 & 374 \\
\hline & & & $p p^{\prime} \mathrm{DDT}$ & $<$ d.l. & $<$ d.l. & $1.22 \pm 0.21^{*}$ & 1.19 & 4.77 \\
\hline & & & tDDT & $<$ d.l. & $0.37 \pm 0.06$ & $2.52 \pm 0.43$ & 3.89 & $\mathbf{5 1 . 7}$ \\
\hline & & & $S Q G-Q D D T S$ & 0.00 & 0.02 & 0.12 & & \\
\hline & & & SQG-Q Organic & 0.01 & 0.09 & 0.11 & & \\
\hline & & & SQG-Q Total & 0.06 & 0.33 & 0.28 & & \\
\hline & & & Overall rating & Unimpacted & Moderately impacted & Moderately impacted & & \\
\hline
\end{tabular}

$<$ d.l., below detection limit; *, value above TEL; ${ }^{* *}$, value above PEL; Eh, sediment redox potential; FF, sediment fine fraction (particle size < $0.63 \mu \mathrm{m}$ ); $N G$, no guideline available; PEL, probable effects level guideline; $S Q G-Q$, Sediment Quality Guideline quotient; TEL; threshold effects level guideline; TOM, total organic matter. Contaminant concentration ranges indicate the standard quantification error. 


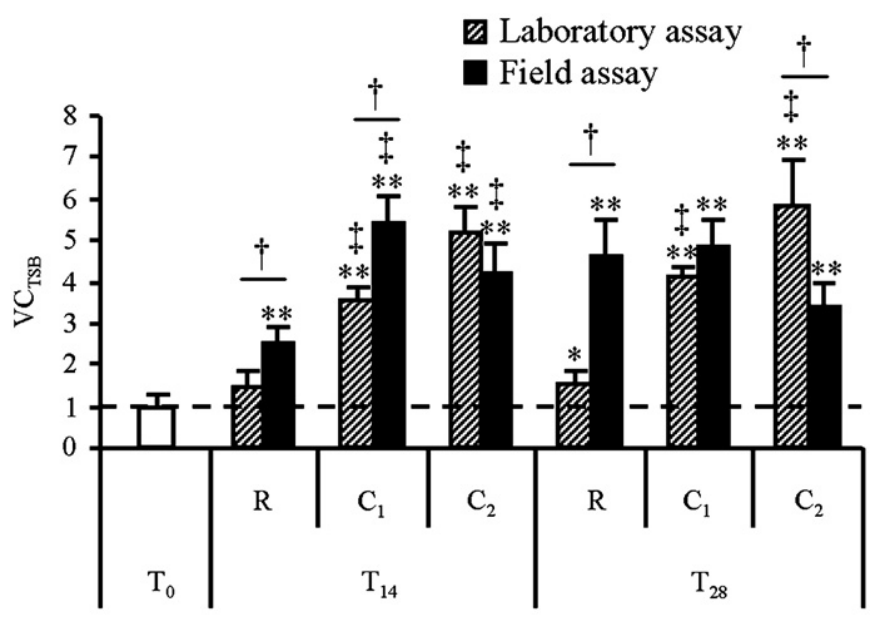

Test and sampling time

Fig. 2. Variation coefficients of total DNA strand breakage $\left(\mathrm{VC}_{\mathrm{TSB}}\right)$ in whole-blood of tested individuals in relation to $T_{0}$ animals (dashed line), as determined by SCGE. * and ${ }^{* *}$ mean significant differences from $T_{0}$ fish (Mann-Whitney $U$ ), $P<0.05$ and $<0.01$, respectively. $\$$ Means significant differences to reference test (exposure to sediment $\mathrm{R}$ ) at respective sampling time and assay type (MannWhitney $U, P<0.01)$. † Means significant differences between laboratory- and field-exposed fish (Mann-Whitney $U, P<0.01$ ). Error bars represent 95\% confidence intervals.

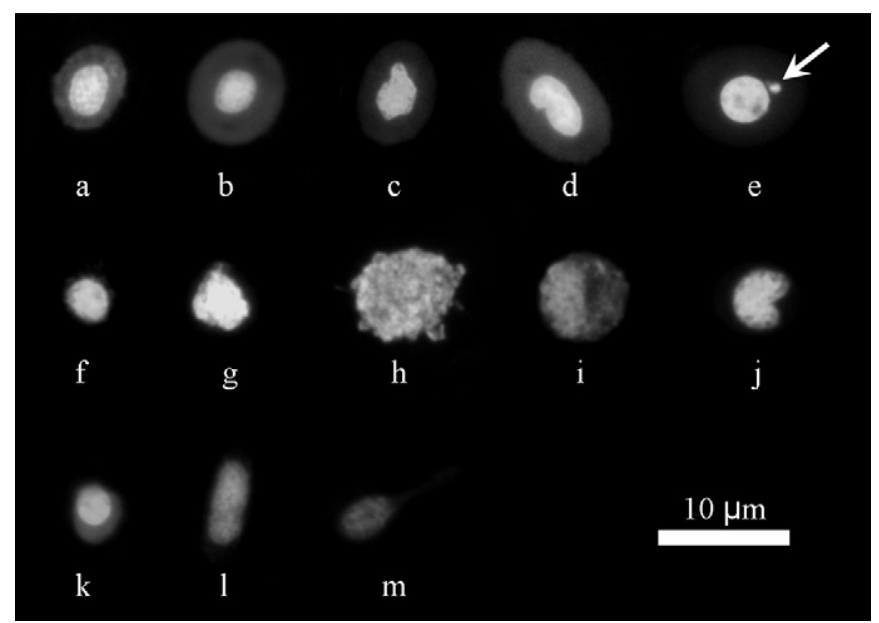

Fig. 3. Representative micrographs of observed cell types and alterations: (a-e) erythrocytes: (a) normal immature erythrocyte; (b) normal mature erythrocyte; (c-e) mature erythrocytes exhibiting nuclear abnormalities such as (c) budding nucleus, (d) bilobed (fragmenting) nucleus and (e) micronucleus (arrow). (f-j) Leukocytes: (f-h) different sized lymphocytes; (i) neutrophil and $(\mathrm{j})$ monocyte. (k$\mathrm{m})$ Thrombocytes: (k) round; (l) rectangular (the most common sort) and $(\mathrm{m})$ spindle-shaped.

observed from $T_{14}$ to $T_{28}$ for any field test (Mann-Whitney $U$, $P>0.05$ ), whereas in the laboratory assay the opposite was observed, including in test R. Unlike the laboratory assay, field exposure to the reference sediment did not cause any significant increase in clastogenesis relatively to $T_{0}$ at $T_{14}$ or even at $T_{28}$ (Mann-Whitney $U, P>0.05$ ). No differences were found between replicates (Kruskall-Wallis $H, P>0.05$ ).

\subsection{Blood plasma lipid peroxidation}

Only field exposure to the tested sediments produced a significant increase in plasma lipid peroxides (inferred from TBARS variation) comparatively to $T_{0}$ fish and no significant differences were found between tests $C_{1}$ and $C_{2}$ to test $R$

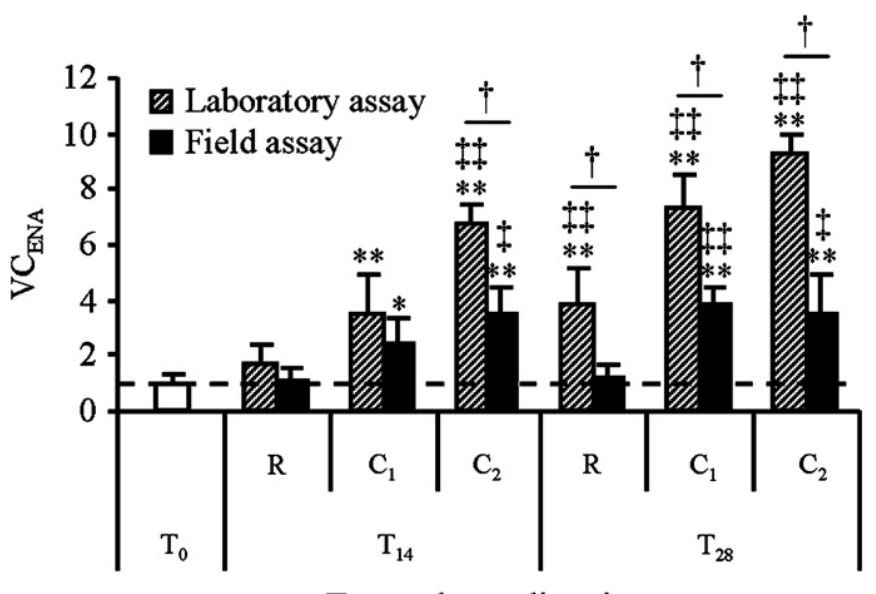

Test and sampling time

Fig. 4. Variation coefficients of the percentage of mature red blood cells exhibiting erythrocytic nuclear abnormalities $\left(\mathrm{VC}_{\mathrm{ENA}}\right)$ comparatively to $T_{0}$ animals (dashed line). *and ${ }^{* *}$ mean significant differences from $T_{0}$ fish (Mann-Whitney $U$ ), $P<0.05$ and $<0.01$, respectively. $\$$ and $\$ \neq$ mean significant differences to reference test (exposure to sediment $\mathrm{R}$ ) at respective sampling time and assay type (MannWhitney $U, P<0.05$ and $<0.01$, respectively). $\dagger$ Means significant differences between laboratory- and field-exposed fish (Mann-Whitney $U, P<0.01$ ). Error bars represent $95 \%$ confidence intervals.

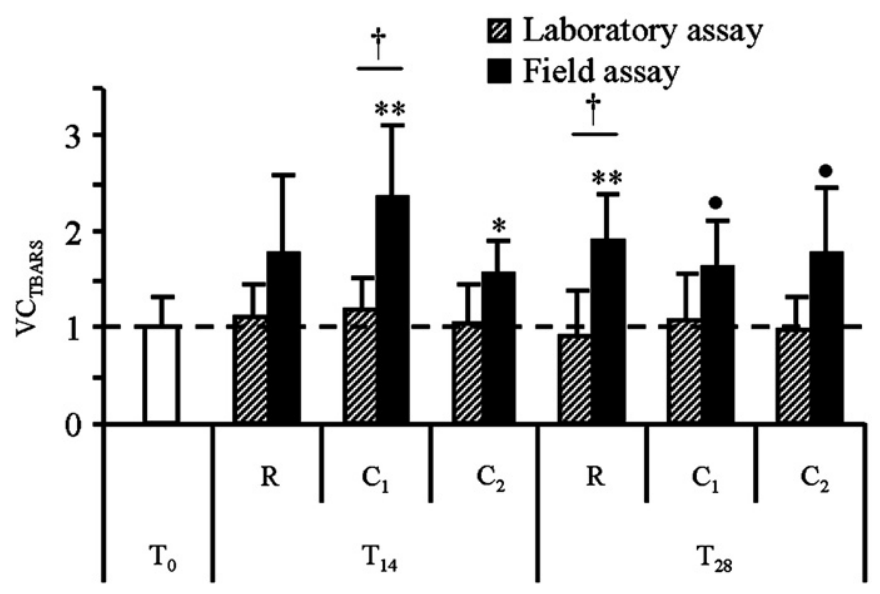

Test and sampling time

Fig. 5. Variation coefficients of lipid peroxide-like substances $\left(\mathrm{VC}_{\mathrm{TBARS}}\right)$ in blood plasma relatively to $T_{0}$ animals (dashed line), as determined by the thiobarbituric acid-reactive species test. $\bullet{ }^{*}$ and ${ }^{* *}$ mean significant differences from $T_{0}$ fish (Mann-Whitney $U$ ), $P<0.10,<0.05$ and $<0.01$, respectively. $\dagger$ Means significant differences between laboratory- and field-exposed fish (Mann-Whitney $U$, $P<0.01$ ). Error bars represent $95 \%$ confidence intervals.

(reference) for either type of assay (Fig. 5). However, whereas field-exposures to sediments $C_{1}$ and $C_{2}$ caused a significant increase in $V C_{\text {TBARS }}$ from $T_{0}$ to $T_{14}$, exposure to the reference sediment depicted the most significant increase from $T_{0}$ fish but after 28 days of exposure (Mann-Whitney $U, P<0.01$ ), although no differences were found for R-tested fish (in the field) between $T_{14}$ and $T_{28}$. No differences were found between replicates (Kruskall-Wallis $H, P>0.05$ ).

\subsection{Quantification of blood cell types}

The percentages of immature erythrocytes (Fig. 3a), leukocytes (Fig. $3 \mathrm{f}-\mathrm{j}$ ) and thrombocytes (Fig. $3 \mathrm{k}-\mathrm{m}$ ) were found to be highly variable within all tested fish (Fig. 6). Exposure to the reference sediment caused a significant decrease in total leukocyte counts, 
at $T_{14}$ (field assay) and $T_{28}$ (laboratory assay). Non-lymphocyte leukocyte counts were found to be very low, regardless of test ( $\approx 0.1-0.5 \%$ ), hence alterations in leukocyte numbers were mostly contributed by lymphocytes. At $T_{28}$, in laboratory-tested fish, the leukocyte percentage was found to be significantly higher in fish exposed to sediment $C_{2}$ comparatively to $R$ - and $C_{1}$-tested fish. (Mann-Whitney $U, P<0.01$ ). In the field assays, again at $T_{28}$, both exposures to $C_{1}$ and $C_{2}$ produced significant higher leukocyte proportions comparatively to test $\mathrm{R}$ (Mann-Whitney $U, P<0.05$ and $<0.01$, respectively) but no significant differences were found between tests $C_{1}$ and $C_{2}$ and no differences were found between laboratory and field-tested fish regarding these two tests. No significant differences were found for other cell types. No differences were found between replicates (Kruskall-Wallis $H, P>0.05)$.

\subsection{Statistical integration of data}

Principal component analysis comprising all biological plus $S Q G-Q$ s (for total, metallic, organic, PAH, PCB and DDT contamination) retrieved the global model for laboratory-tested fish as the one explaining the highest percentage of total observed variance, followed by the laboratory + field- and field-tested fish models (cumulative explained variance on factors 1 and 2 was $63 \%, 60 \%$ and $57 \%$, respectively). For all models, the genotoxicity variation coefficients $\left(V C_{\mathrm{ENA}}\right.$ and $\left.V C_{\mathrm{TSB}}\right)$, together with the percentage of leukocytes in blood, appeared more strongly correlated to the sediment quality guideline quotients (SQG-Qs), while a distinct group comprises the size-related variables $\left(L_{\mathrm{s}}\right.$ and $w w_{\mathrm{t}}$ ), the variation coefficients of TBARS (VC $\left.C_{\mathrm{TBARS}}\right)$ and the percentage of thrombocytes (Fig. 7). However, $V C_{\mathrm{ENA}}$ and $V C_{\mathrm{TSB}}$ were found to provide a greater contribution to the laboratory assay's PCA than in the field assay's $(0.088,0.058$ and 0.025 and 0.061 on factor 1 , respectively), as well as they reverse their relative importance. On the other hand, the percentage of immature erythrocytes is better correlated with fish size in the field assay's PCA and with the sediment contamination indices in the laboratory assay's. The segregation of sampled animals (all biological variables) according to sampling time ( $T_{14}$ versus $T_{28}$ ) by means of discriminant analysis reveals a better separation of laboratory-, field-tested and reared animals (fish collected at $T_{0}$ ) after 28 days of exposure, which is translated into the lowest Wilks' $\lambda$ and percentage of incorrect case classifications (Fig. 8).

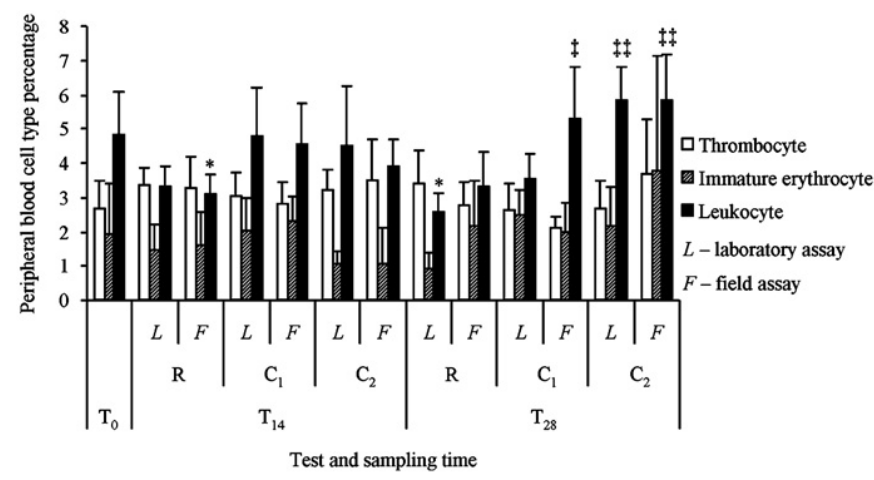

Fig. 6. Average thrombocyte, immature erythrocyte and leukocyte percentages in fish exposed to sediments from stations $R, C_{1}$ and $C_{2} .{ }^{*}$ means differences from $\mathrm{T}_{0}$-fish, $P<0.05$ (Mann-Whitney $U$ ). $\$$ and $\$+$ mean significant differences to reference test (exposure to sediment $\mathrm{R}$ ) at respective sampling time and assay type (Mann-Whitney $U, P<0.05$ and $P<0.01$, respectively). Error bars represent $95 \%$ confidence intervals.

\section{Discussion and conclusions}

Ecological risk assessment of contaminated sediments is a difficult task not only due to the likely occurrence of antagonist and synergistic effects drawn by mixtures of contaminants but also to the complex physico-chemical nature of the sediments themselves and its consequence on bioavailability. The integration of toxicity responses and effects in organisms with sediment quality guidelines and respective indices for contaminant mixtures (the SQG-Qs employed in the current work) should provide a more realistic approach to estimate the probability of occurring adverse affects to organisms than simple xenobiotic concentrations in the sediments since these indices are based on large datasets from multiple organisms, sediment types and contaminant classes (Long and MacDonald, 1998; Chapman et al., 2002). The present findings suggest that sediments $C_{1}$ and $C_{2}$, found to be overall moderately contaminated according to $S Q G-Q s$, induced genotoxicity in both laboratory and field assays. However, the two types of bioassays yielded different patterns of genotoxicity, oxidative stress status and even mortality, which are likely caused by differences in the assays' conditions that affect bioavailability and overall fish stress and health status.

Comparing the levels of contaminants present in the tested sediments (collected in the spring of 2007) to the levels obtained in previous research at the same locations during the preceding autumn (Costa et al., 2008a, 2009a, 2009b) it may be inferred that the contaminant concentrations are within the expected order of magnitude. Still, a considerable rise in the levels of metals has occurred from autumn to spring regarding sediment $C_{2}$, especially regarding $\mathrm{Cr}$ and $\mathrm{Zn}$, more than two- and three-fold, respectively. Conversely, PAH levels have moderately increased from the previous survey in sediments $C_{1}$ and $C_{2}$ (caused especially by an increase by almost the double of the concentrations of fluoranthene and pyrene), although $C_{2}$ remained the most contaminated by these substances and PCBs, within a similar scale of contamination. The reference sediment's levels of contamination decreased for all classes of xenobiotics, from autumn to spring. Nevertheless, sediment $C_{1}$ retains the status of the most contaminated and, according to the analysis of $S Q G-Q s$, the probability of causing adverse effects may rank the tested sediments in the order: $\mathrm{R}<\mathrm{C}_{2}<\mathrm{C}_{1}$ for element contaminants and total contamination and $\mathrm{R}<\mathrm{C}_{1}<\mathrm{C}_{2}$ for organic xenobiotics. Still, PAHs are the major xenobiotic class of concern among organic contaminants since organochlorines are overall poorly represented. The observed alterations in the sediments' contaminant levels from autumn to spring sampling may be explained by variation in grain size, seasonality (influencing, e.g. freshwater intake), natural depositing of contaminants that are continuously being released from pollution hotspots. Point local variations in sediment geochemistry may have a significant weight, such as the fact that the new site $\mathrm{C}_{2}$ is located inside a recent harbor that has been subjected to dredging and settlement of a new sediment layer. In general, however, the results from sediment chemistry are in accordance with the ecological risk determined for the study area from past research (Caeiro et al., 2009).

In spite of the differences observed concerning the concentrations of some metals and organic compounds, DNA fragmentation and chromosomal clastogenesis depicted a similar pattern to our previous work with laboratory exposure to sediments from proximate locations (see Costa et al., 2008a). Still, some differences in the toxicity patterns between field and laboratory assays were observed, especially regarding the genotoxicity biomarkers (ENA and TSB) and lipid peroxides in plasma. These differences may be explained by two sets of factors: (i) factors that potentially enhanced bioavailability of contaminants, increasing the toxicity of sediment-bound xenobiotics in the 
a

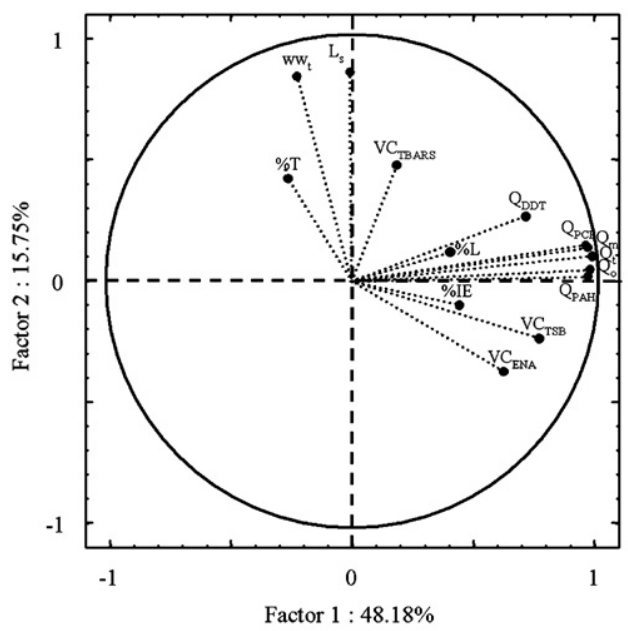

b

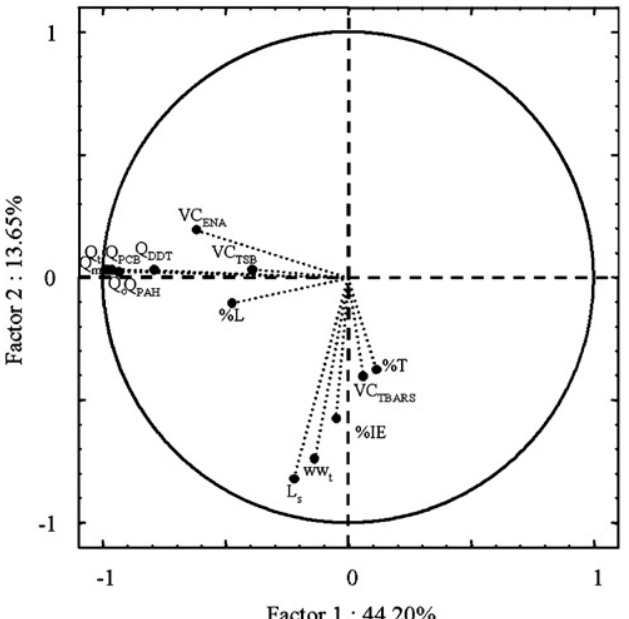

C

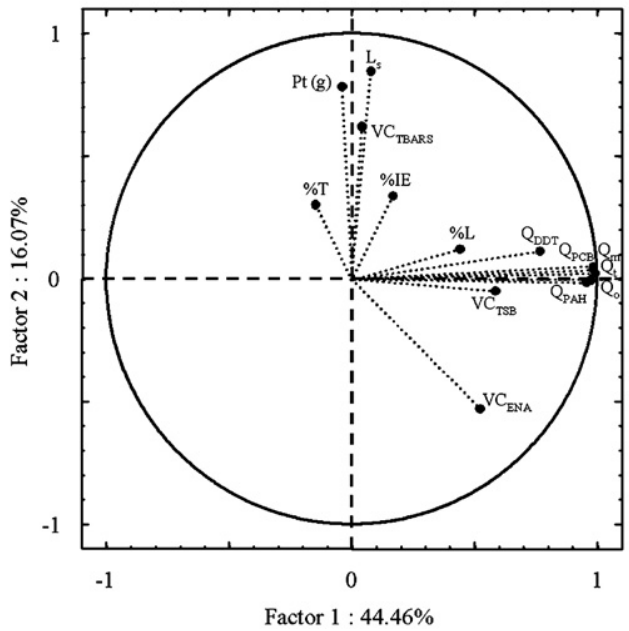

Fig. 7. Scatterplot of the principal component analysis (PCA) results (combination of $T_{14}$ - and $T_{28}$-collected fish): (a) laboratory assay (factor 1 eigenvalue $=6.74$; factor 2 eigenvalue $=2.20$ ); (b) field assay (factor 1 eigenvalue $=6.19$; factor 2 eigenvalue $=1.91$ ) and (c) global PCA, combining laboratory- and field-tested fish (factor 1 eigenvalue $=6.22$; factor 2 eigenvalue $=2.25$ ). \%IE, percentage of immature erythrocytes; \%L, percentage of leukocytes; \%T, percentage of thrombocytes; $Q_{D D T}, S Q G$ - $Q$ for DDTs; $Q_{\mathrm{m}}, S Q G-Q$ for metallic contaminants; $Q_{0}, S Q G-Q$ for organic contaminants; $Q_{P A H}, S Q G-Q$ for PAHs; $Q_{P C B}, S Q G-Q$ for PCBs; $Q_{t}, S Q G-Q$ for total contaminants; VC $C_{\mathrm{ENA}}$ $V C_{\mathrm{TBARS}}$ and $V C_{\mathrm{TSB}}$, variation coefficients for erythrocytic nuclear abnormalities, thiobarbituric acid reactive substances and total DNA strand breakage, respectively.

laboratory and enhancing the effects of their interactions and (ii) environmental factors that influenced genotoxicity and lipid peroxidation (mainly by predisposing oxidative stress) in fieldtested fish.

Sediment organic matter and fine particle fraction operate as traps for contaminants. When subjected to disturbance, especially when combined with oxic-anoxic shifting, xenobiotics sorpted to organic matter- and fine fraction-rich sediments may be transferred to the water column, increasing their bioavailability, especially if a shift in the redox/pH status occurs, for instance, due to access of dissolved oxygen (see Eggleton and Thomas, 2004). It is thus likely that sediment collection and handling during the preparation of the laboratory assays favoured the release of xenobiotics from the sediment matrix to the water by a combination of disturbance upon collecting and handling, and also animal-driven resuspension, and the air flow that continuously oxygenated the water and upper layer of sediments, thus contributing to the change of its redox status. This may contribute to explain why ENA suffered a greater increase in laboratorytested fish comparatively to $T_{0}$ animals (which reflect the standard rearing conditions). Still, genotoxicity resulting from laboratory exposures was higher regarding exposure to sediment
$\mathrm{C}_{2}$, the sediment most contaminated by PAHs but not the globally most impacted. However, exposure to sediment $C_{1}$ (the most impacted) caused the only significant increase in TSB from $T_{14}$ to $T_{28}$. This "delay" in the induction of DNA strand breakage is in accordance with our previous results and substantiates the hypothesis that contaminant interactions (especially PAH versus metallic contaminants) might be important confounding factors for this biomarker (Costa et al., 2008a). In fact, antagonistic interactions between $\mathrm{PAH}$ and metals have already been described, occurring as a result of the inhibition by metals of the cytochrome P450 (CYP1A)-mediated PAH activation (e.g. Vakharia et al., 2001; Spink et al., 2002). Since PAHs have low solubility in water, cells promote detoxification by activating these compounds, converting them into the more soluble, highly reactive, PAH-quinones and the highly genotoxic PAH diolepoxides, with production of ROS, a reaction that is normally catalyzed by the microsomal cytochrome complexes (Lemaire and Livingstone, 1997). Detoxification of PAHs is therefore a catabolic reaction that enhances mutagenicity by action of its activated (electrophilic) by-products that form adducts with the DNA molecules, promoting strand instability and eventual fragmentation, besides the direct action of ROS. Even though the 
a

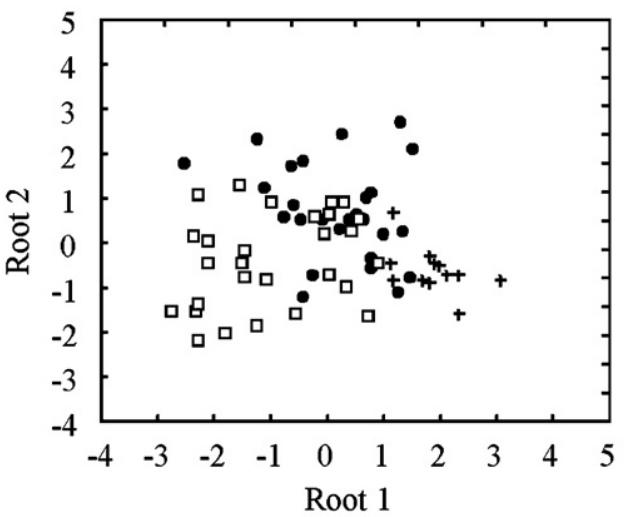

b

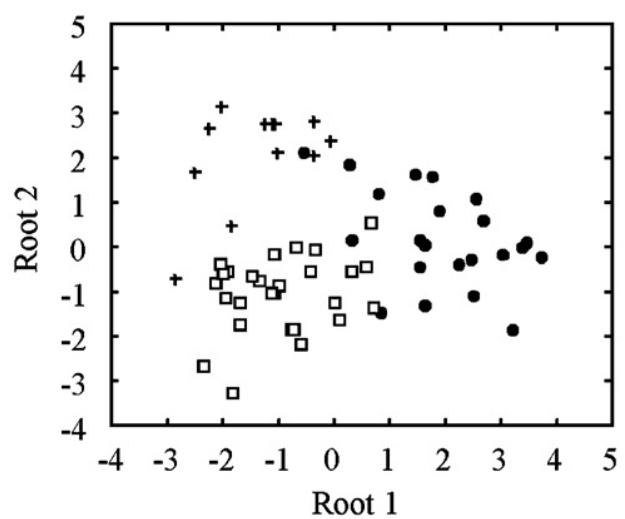

C

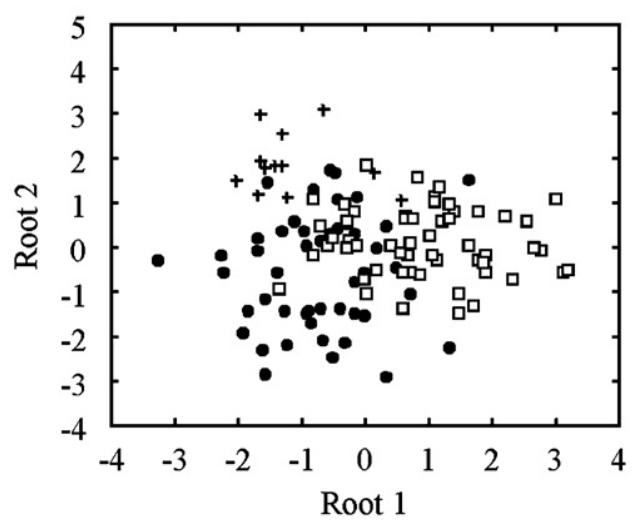

Fig. 8. Discriminant analysis scatterplots, all-biological variable models combining fish exposed to the three tested sediments: (a) fish collected at $T_{14}$ plus $T_{0}$ (Wilks' $\lambda=0.35,26 \%$ incorrect classifications); (b) Fish collected at $T_{28}$ plus $T_{0}$ (Wilks' $\lambda=0.13 ; 13 \%$ incorrect classifications) and (c) global model comprising animals collected at all sampling times (Wilks' $\lambda=0.36 ; 24 \%$ incorrect classifications).

liver is the primary vertebrate organ where xenobiotics are metabolized, ROS and other mutagenic substances are likely to spread via peripheral blood and affect blood cells and haematopoietic tissue. Conversely, inhibition of CYP1A activity might have reduced mutagenicity by liberating less genotoxic compounds into the blood stream. Chromosomal clastogenesis has also been linked to the formation of ROS (Soto-Reyes et al., $2005)$, which helps explaining the similar pattern of $V C_{\mathrm{TSB}}$ and $V C_{\mathrm{ENA}}$ in laboratory-tested fish and $V C_{\mathrm{ENA}}$ in field-tested individuals. Organochlorines, like DDT and its metabolites, are also known to cause DNA strand fragmentation, as measured by the SCGE (e.g. Yáñez et al., 2004). However, the low concentrations of organochlorines (translated into much lower SQG-Qs than for metals and PAHs) observed in the tested sediments make it difficult to determine their exact contribution to a potential synergistic or antagonistic effect on the observed TSB variation coefficients.

It should also be taken into consideration that there is evidence that many of the surveyed metals are known genotoxicants, even though the mechanisms of metal-induced mutagenesis remain somewhat unclear. Unlike activated PAHs, for instance, which may react directly with DNA, this effect is more indirect (e.g. by unbalancing oxidative metabolism and inhibiting DNA repair). It is the case, for instance of $\mathrm{As}, \mathrm{Cd}, \mathrm{Co}, \mathrm{Cr}, \mathrm{Ni}$, and $\mathrm{Pb}$ (Hartwig, 1995) and both organic and inorganic species of $\mathrm{Hg}$ (Crespo-López et al., 2009). Since from the total SQG-Q for metals is higher for the sediment $C_{1}$ than for $C_{2}(0.79$ and 0.58 , respectively), this is yet another factor that allows a suspicion on the negative interactions between organic and metallic contaminants.
Field-tested fish, however, reveal a distinct pattern of induction of DNA strand damage. After 14 days of exposure $\left(T_{14}\right)$, test $C_{1}$ was the responsible for the greatest increment in TSB. At $T_{28}$, though, exposure to the reference sediment resulted in the highest increase in TSB whereas tests $C_{1}$ and $C_{2}$ remained unchanged. This increase in TSB as a result of exposure to the reference sediment is unlikely linked to sediment contamination. However, this effect is accompanied by a very significant increase in blood plasma lipid peroxides from $T_{0}$ to $T_{28}$ in field-exposed fish to the reference sediment. Since no alteration were observed regarding leukocyte counts, therefore excluding the action of natural parasites, it may be inferred that an unknown factor was responsible for the increase of $V C_{\mathrm{TBARS}}$ and $V C_{\mathrm{TSB}}$ in field-exposed fish to sediment $R$. One of the most plausible reasons is the oxidative stress originated by food deprivation. Site $\mathrm{R}$ is subjected to strong tidal currents and, when the animals were collected at $T_{28}$, sediment was observed to have been partially washed off from underneath the cage apparatus. Most animals were in fact found having empty digestive tracts, unlike fish allocated in stations $C_{1}$ and $C_{2}$, inside which remains of small gastropods and bivalves were commonly found. Senegalese soles are known to occupy sandy or muddy bottoms where they forage on small benthic invertebrates (Cabral, 2000). Starvation has been found to increase lipid peroxidation in teleosts (Pascual et al., 2003; Morales et al., 2004). Lipid peroxides result from the formation of ROS, for instance by depletion of anti-oxidant molecules like reduced glutathione (GSH) as a consequence of oxidative tissue damage (Robinson et al., 1997). It is therefore possible that fish tested on site $\mathrm{R}$ were deprived of food, e.g., by sediment washingoff, which is likely to have caused oxidative stress, resulting in an 
increase in both TBARS and TSB. It may also be one of the factors involved in the unexpected high mortality that occurred during this test. DNA oxidation has been described as a major mutagenic factor in organisms exposed to environmental xenobiotics (reviewed by Azqueta et al., 2009). It is also important to notice that changes in feed composition (affecting, e.g. availability of anti-oxidant elements like Se, dietary fat composition, etc.) might have had a significant role. A moderate but significant correlation was found between $V C_{\mathrm{TBARS}}$ and $V C_{\mathrm{TSB}}(\rho=0.26, P<0.01)$ for all tested fish, from which may be inferred that a factor affecting both markers (like oxidative stress) may, at least partially, explain these results. Considering this information, it may also be argued that the lack of significant variation TBARS in laboratory-exposed fish may be, at least in part, explained by the combination of: reduction of oxidative stress by metal $\times$ organic contaminant interactions in tests $C_{1}$ and $C_{2}$; the reduced toxicity of the reference sediment and the controlled access to food. The lack of a clear relationship between environmental contamination and genotoxicity plus lipid peroxidation has already been described by other authors who proposed that unaccounted environmental and biological variables are important and require further research (e.g. Shaw et al., 2004). This relationship is also not clear at cellular and molecular levels and some authors have proposed that, independently of the oxidative offense, DNA strand breakage always depends on intrinsic factors such as cell division rates and DNA repair capability (Duthie and Collins, 1997; Hu et al., 1998).

Chromosomal clastogenesis, given by ENA, was apparently less susceptible to be affected by background variables than TSB, especially in the field assays where no significantly higher ENA frequencies in fish exposed to the reference sediment for 14 or 28 days, comparatively to $T_{0}$, were found. These results may derive from the different nature of the two types of mutagenicity: whereas TSB results from direct action of mutagens on the DNA chains, causing fragmentation, adducts and alkali-labile (chemically altered nucleotide) sites; ENA (like micronuclei) are considered to be linked to errors during the mitotic process, leading to DNA damage like chromosome fragmentation, failed segregation during nuclear division and isolation of whole chromosomes, and may thus magnify baseline DNA strand breakage (e.g. Schiffmann and de Boni, 1991; Neuparth et al., 2009). Although $V C_{\mathrm{ENA}}$ and $V C_{\mathrm{TSB}}$ were significantly correlated $(\rho=0.45, P<0.01)$, a moderate negative correlation was found between $V C_{\text {ENA }}$ and $V C_{\text {TBARS }}(\rho=-0.28, P<0.01)$, which is yet another evidence for the different mechanisms underlying the two types of mutagenesis. Considering that single-strand damage is repairable by DNA polymerases and ligases, clastogenesis might be considered a more severe type of mutagenesis. At some extent, as for DNA TSB, chromosomal clastogenesis has been found linked to oxidative stress (Cicchetti and Argentin, 2003) and therefore, an antagonist interaction between the different classes of contaminants may account for the similar pattern between $V C_{\mathrm{TSB}}$ and $V_{\text {ENA }}$ within laboratory and field assays. It is also of notice that organochlorines (like PCBs and DDTs) are long known to be clastogenic (Hose et al., 1984, 1987). Still, the concentrations of the latest in the surveyed sediments were low, (highest SQG-Qs for PCBs and DDTs were 0.06 and 0.12 , respectively, for sediment $\mathrm{C}_{2}$ ) and were likely masked by metallic elements and PAHs, also known clastogenic compounds (e.g. Hose et al., 1984; Siu et al., 2004; Çavas et al., 2005).

Peripheral blood lymphocyte proliferation has already been described as an effect of exposure to PAHs (Reynaud and Deschaux, 2005). On the contrary, Khan (2003) found reduced lymphocyte counts in feral flatfish collected from sites subjected to mixed classes of contaminants, especially PCBs and PAHs. Our study did not reveal any significant increase in leukocyte percentages between fish exposed to any of the sediments and $T_{0}$ animals. However, exposure to sediment $C_{2}$ (the most contaminated by PAHs), both in the laboratory and in the field, yielded a significant increase in leukocyte counts (i.e. lymphocyte, since other immune cells were rare) after 28 days of exposure, comparatively to the exposure to the reference sediment. In the field assays, the same was observed for sediment $C_{1}$. These results suggest that exposure to the most contaminated sediments induced proliferation of peripheral lymphocytes; however, this comparison was only noticeable after a prolonged exposure. It should also be taken into consideration that $T_{0}$ fish essentially reflect the rearing conditions. Husbandry parameters such as population density may cause differences in the global immunological parameters of fish. Although the correlation between lymphocyte percentages, sediment contamination indices and genotoxicity biomarkers could indicate some potential value for ecological risk assessment, the mechanisms of leukocyte proliferation as a result of exposure to xenobiotics are not clear. Hooghe et al. (2000), for instance, suggested that xenobiotics may inhibit synthesis of cytokines, therefore impairing defense cell proliferation, which is not supported by the present findings. It may be inferred that, although possibly modulated by the presence of xenobiotics, caution is mandatory when considering this parameter as an indicator of exposure.

The present findings suggest that laboratory and field (in situ) assays may produce distinct results regarding the assessment of the genotoxic potential of sediment-bound contamination. Still, both yielded genotoxicity data globally consistent with sediment contamination. Overall, clastogenesis appears to better reflect the levels of sediment contamination in the field assays than total DNA strand breakage, a result that is in accordance with findings from other authors such as Wirzinger et al. (2007) with feral sticklebacks. Still, measuring DNA damage at the molecular level (as with the SCGE) is a more objective and sensitive method. Our results confirm the suitability of employing both bioassay methods to detect the genotoxic potential of sediment contaminants. We have also shown that oxidative stress biomarkers such as lipid peroxidation might be affected by factors external to contamination, although they may complement and aid the interpretation of genotoxicity data. Cell type sorting, however, revealed highly variable data that may produce ambiguous or unclear results although leukocyte/lymphocyte counts may be of use when combined with other indicators and biomarkers perhaps as a general indicator of stress. This type of analysis might also be important, e.g., to infer the overall fish health status as a potential background variable in bioassays. Both types of bioassays (laboratory and in situ) are useful tools but each has its own advantages and handicaps. Laboratory assays might eliminate some background variability of the measured effects and responses but may also unleash the full potential of contamination by favouring bioavailability, e.g. through sediment disturbance. Laboratory assays are especially useful when the main objective consists of assessing the net genotoxic potential (or its mechanisms) of contaminant mixtures, for instance as it might occur in the natural environment following sediment disturbance events (common in estuaries), such as dredgings, storms and strong tides or river flows. Still, it should also be taken into consideration that laboratory tests are likely to induce stress to animals, raising the background noise that will be cumulative with toxicity effects, which may, at least in part, account for the mortality observed in the laboratory tests. Field studies may be more representative of the standard situation in a natural environment but are more susceptible to noise variables that induce variability, like food availability and other environmental parameters that are very variable in estuaries such as salinity and temperature fluctuations, complex hydrodynamics, etc., just to 
mention abiotic factors. Complementarily, our study showed that the use of sediment quality guidelines and contamination indices instead of net contaminant levels to compare the genotoxic potential of sediments with complex contaminant mixtures and that these indices provide a more realistic approach to interpreting data, especially from field assays, since laboratory tests are likely to magnify the effects of toxicity. The complexity of sediment contaminant mixtures and the effects of xenobiotic interactions need yet much research, especially when the toxic substances are not present in such high levels to provide obvious differences in adverse effects to organisms.

To summarize, using fish peripheral blood to detect the genotoxic potential of sediment contamination is an expedite procedure capable of producing much information but integration with other blood parameters such as lipid peroxidation and cell sorting might be, at least, a useful guide to detect the effects of background variables. Although laboratory and field assays are useful tools, the choice for one of them should be based on a careful balance of advantages and disadvantages and always according to the real objectives of the study. Laboratory tests appear to be good tools for eliminating environmental variables and are more expedite and less expensive to perform. It is also possible that laboratory assays enhance the potential of sediment bound toxicants, thus providing a more conservative approach to biomonitoring procedures. However, field assays are likely to provide ecologically more realistic information, therefore more relevant for regulatory purposes.

\section{Acknowledgments}

The present research was approved by the Portuguese Science and Technology Foundation (FCT) and Programa Operacional Ciência, Tecnologia e Inovação (POCTI, research project ref. POCTI/ AMB 57281/104) and financed by FEDER (European Fund for Regional Development). P.M. Costa is supported by a FCT Ph.D. grant (SFRH/BD/28465/2006). The authors would also like to thank APSS (Administração dos Portos de Setúbal e Sesimbra, SA) and J. Raimundo, V. Branco, R. Cesário and P. Pousão (IPIMARINRB) for their support.

\section{References}

Azqueta, A., Shaposhnikov, A., Collins, A.R., 2009. DNA oxidation: investigating its key role in environmental mutagenesis with the comet assay. Mutat. Res. 674, 101-108.

Bombail, V., Aw, D., Gordon, E., Batty, J., 2001. Application of the comet and micronucleus assay to butterfish (Phollis gunnellus) erythrocytes from the Firth of Forth, Scotland. Chemosphere 44, 383-392.

Bradfield, W., Pye, A., Clifford, T., Salter, L., Gould, D., Campbell, S., Curnow, A., 2006. $\mathrm{Hg}$ (II) exposure exacerbates UV-induced DNA damage in MRC5 fibroblasts: a comet assay study. J. Environ. Sci. Health A 41, 143-148.

Budzinski, H., Jones, I., Bellocq, J., Piérard, C., Garrigues, P., 1997. Evaluation of sediment contamination by polycyclic aromatic hydrocarbons in the Gironde estuary. Mar. Chem. 58, 85-97.

Cabral, H.N., 2000. Comparative feeding ecology of sympatric Solea solea and S. senegalensis, within the nursery areas of the Tagus estuary, Portugal. J. Fish Biol. 57, 1550-1562.

Caeiro, S., Costa, M.H., DelValls, A., Repolho, T., Gonçalves, M., Mosca, A., Coimbra, A.P., Ramos, T.B., Painho, M., 2009. Ecological risk assessment of sediment management areas: application to Sado Esturary, Portugal. Ecotoxicology 18, 1165-1175.

Caeiro, S., Costa, M.H., Ramos, T.B., Fernandes, F., Silveira, N., Coimbra, A., Medeiros, G., Painho, M., 2005. Assessing heavy metal contamination in Sado Estuary sediment: an index analysis approach. Ecol. Indicators 5, 151-169.

Caetano, M., Fonseca, N., Cesário, R., Vale, C., 2007. Mobility of Pb in salt marshes recorded by total content and stable isotopic signature. Sci. Total Environ. 380, 84-92.

Çavas, T., Garanko, N.B., Arkhipchuk, V.V., 2005. Induction of micronuclei and binuclei in blood, gill and liver cells of fishes subchronically exposed to cadmium chloride and copper sulphate. Food Chem. Toxicol. 43, 569-574.
Chapman, P.M., Ho, K.T., Munns Jr., W.R., Solomon, K., Weinstein, M.P., 2002. Issues in sediment toxicity and ecological risk assessment. Mar. Pollut. Bull. 44, 271-278.

Chen, G., White, P.A., 2004. The mutagenic hazards of aquatic sediments: a review. Mutat. Res. 567, 151-225.

Cicchetti, R., Argentin, G., 2003. The role of oxidative stress in the in vitro induction of micronuclei by pesticides in mouse lung fibroblasts. Mutagenesis 18, $127-132$.

Costa, P.M., Costa, M.H., 2007. Genotoxicity assessment in fish peripheral blood: a method for a more efficient analysis of micronuclei. J. Fish Biol. 71 (SA), 148-151.

Costa, P.M., Lobo, J., Caeiro, S., Martins, M., Ferreira, A.M., Caetano, M., Vale, C., DelValls, T.A., Costa, M.H., 2008a. Genotoxic damage in Solea senegalensis exposed to sediments from the Sado Estuary (Portugal): effects of metallic and organic contaminants. Mutat. Res. 654, 29-37.

Costa, P.M., Repolho, T., Diniz, M.E., Moura, I., Costa, M.H., 2008b. Modelling metallothionein induction in the liver of Sparus aurata exposed to metalcontaminated estuarine sediments. Ecotoxicol. Environ. Saf. 71, 117-124.

Costa, P.M., Caeiro, S., Diniz, M., Lobo, J., Martins, M., Ferreira, A.M., Caetano, M., Vale, C., DelValls, T.À., Costa, M.H., 2009a. Biochemical endpoints on juvenile Solea senegalensis exposed to estuarine sediments: the effects of contaminant mixtures on metallothionein and CYP1A induction. Ecotoxicology 18, 988-1000.

Costa, P.M., Diniz, M.S., Caeiro, S., Lobo, J., Martins, M., Ferreira, A.M., Caetano, M., Vale, C., DelValls, T., Costa, M.H., 2009b. Histological biomarkers in liver and gills of juvenile Solea senegalensis exposed to contaminated estuarine sediment: a weighted indices approach. Aquat. Toxicol. 92, 202-212.

Costley, C.T., Mossop, K.F., Dean, J.R., Garden, L.M., Marshall, J., Carroll, J., 2000. Determination of mercury in environmental and biological samples using pyrolysis atomic adsorption spectrometry with gold amalgamation. Anal. Chim. Acta 405, 179-183.

Crespo-López, M.E., Macêdo, G.L., Pereira, S.I.D., Arrifano, G.P.F., Picanço-Diniz, D.L.W., do Nascimento, J.L.M., Herculano, A.M., 2009. Mercury and human genotoxicity: critical considerations and possible molecular mechanisms. Pharmacol. Res. 60, 212-220.

Duthie, S.J., Collins, A.R., 1997. The influence of cell growth, detoxifying enzymes and DNA repair and hydrogen peroxide-mediated DNA damage (measured using the comet assay) in human cells. Free Radical Biol. Med. 22, 717-724.

Eggleton, J., Thomas, K.V., 2004. A review of factors affecting the release and bioavailability of contaminants during sediment disturbance events. Environ. Int. 30, 973-980.

Ferreira, A.M., Martins, M., Vale, C., 2003. Influence of diffuse sources on levels and distribution of polychlorinated biphenyls in the Guadiana River estuary, Portugal. Mar. Chem. 89, 175-184.

Gagné, F., Burgeot, T., Hellou, J., St-Jean, S., Farcy, É., Blaise, C., 2008. Spatial variation in biomarkers of Mytilus edulis mussels at four polluted regions spanning the Northern Hemisphere. Environ. Res. 107, 201-217.

Gilbert, H.S., Stump, D.D., Roth Jr., E.F., 1984. A method to correct for errors caused by generation of interfering compounds during erythrocyte lipid peroxidation. Anal. Biochem. 137, 282-286.

Grinevicius, V.M.A.S., Geremias, R., Laus, R., Bettega, K.F., Laranjeiras, M.C.M., Fávere, V.T., Wilhelm Filho, D., Pedrosa, R.C., 2009. Textile effluents induce biomarkers of acute toxicity, oxidative stress and genotoxicity. Arch. Environ. Contam. Toxicol. 57, 307-314.

Hartwig, A., 1995. Current aspects in metal genotoxicity. BioMetals 8, 3-11.

Hatch, A.C., Burton Jr., G.A., 1999. Sediment toxicity and stormwater runoff in a contaminated receiving system: consideration of different bioassays in the laboratory and field. Chemosphere 39, 1001-1017.

Hose, J.E., Hannah, J.B., Puffer, H.W., Landolt, M.L., 1984. Histologic and skeletal abnormalities in benzo(a)pyrene-treated rainbow trout alevins. Arch. Environ. Contam. Toxicol. 13, 675-684.

Hose, J.E., Cross, J.N., Smith, S.G., Diehl, D., 1987. Elevated circulated erythrocyte micronuclei in fishes from contaminated sites off southern California. Mar. Environ. Res. 22, 167-176.

Hooghe, R.J., Devos, S., Hooghe-Peters, E.L., 2000. Effects of selected herbicides on cytokine production in vitro. Life Sci. 66, 2519-2525.

Hu, Y., Su, L., Snow, E.T., 1998. Arsenic toxicity is enzyme specific and its effects in ligation are not caused by the direct inhibition of DNA repair enzymes. Mutat. Res. 408, 203-218.

Johnson, L.L., Landahl, J.T., Kubin, L.A., Horness, B.H., Myers, M.S., Collier, T.K., Stein, J.E., 1998. Assessing the effects of anthropogenic stressors on Puget Sound flatfish populations. J. Sea Res. 39, 125-137.

Khan, R.A., 2003. Health of flatfish from localities in Placentia Bay, Newfoundland, contaminated with petroleum and PCBs. Arch. Environ. Contam. Toxicol. 44, 485-492.

Lee, R.F., Steinert, S., 2003. Use of the single cell gel electrophoresis/comet assay for detecting DNA damage in aquatic (marine and freshwater) animals. Mutat. Res. 544, 43-64.

Lemaire, P., Livingstone, D.R., 1997. Aromatic hydrocarbon quinone-mediated reactive oxygen species production in hepatic microsomes of the flounder (Platichthys flesus L.). Comp. Biochem. Physiol. C 117, 131-139.

Liu, S., Athart, M., Lippai, I., Waldren, C., Hei, T.K., 2001. Induction of oxyradicals by arsenic: Implication for mechanism of genotoxicity. Proc. Natl. Acad. Sci. USA 98, 1643-1648

Long, E.R., MacDonald, D.D., 1998. Recommended uses of empirically derived, sediment quality guidelines for marine and estuarine ecosystems. Hum. Ecol. Risk Assess. 4, 1019-1039. 
López-Barea, J., Gómez-Ariza, J.L., 2006. Environmental proteomics and metallomics. Proteomics 6, S51-S62.

Macdonald, D.D., Carr, S., Calder, F., Long, E., Ingersoll, C., 1996. Development and evaluation of sediment quality guidelines for Florida coastal waters. Ecotoxicology 5, 253-278.

MacDonald, D.D., Carr, R.S., Eckenrod, D., Greening, H., Grabe, S., Ingersoll, C.G., Janicki, S., Janicki, T., Lindskoog, R.A., Long, E.R., Pribble, R., Sloane, G., Smorong, D.E. 2004. Development, evaluation, and application of sediment quality targets fo assessing and managing contaminated sediments in Tampa Bay, Florida. Arch. Environ. Contam. Toxicol. 46, 147-161.

Martins, M., Ferreira, A.M., Vale, C., 2008. The influence of Sarcocornia fruticosa on retention of PAHs in salt marshes sediments (Sado estuary, Portugal). Chemosphere 71, 1599-1606.

Miller, K.P., Ramos, K.S., 2001. Impact of cellular metabolism on the biological effects of benzo[a]pyrene and related hydrocarbons. Drug. Metab. Rev. 33, 1-35.

Moller, P., Knudsen, L.E., Loft, S., Wallin, H., 2000. The comet assay as a rapid test in biomonitoring occupational exposure do DNA-damaging agents and effect of confound factors. Cancer Epidemiol. Biomarkers 9, 1005-1015.

Moore, P.D., Yedjou, G., Thounwou, P.B., 2009. Malathion-induced oxidative stress, cytotoxicity, and genotoxicity in human liver carcinoma $\left(\mathrm{HepG}_{2}\right)$ cells. Environ. Toxicol. 25, 221-226.

Morales, A.E., Pérez-Jiménez, A., Hidalgo, M.C., Abellán, E., Cardenete, G., 2004 Oxidative stress and antioxidant defenses after prolonged starvation on Dentex dentex liver. Comp. Biochem. Phys. C 139, 153-161.

Neuparth, T., Correia, A.D., Costa, F.O., Lima, G., Costa, M.H., 2005. Multi-level assessment of chronic toxicity of estuarine sediments with the amphipod Gammarus locusta: I. Biochemical endpoints. Mar. Environ. Res. 60, 69-91.

Neuparth, T., Costa, F.O., Costa, M.H., Theodorakis, C.W., Bickham, J.W., 2009 Assessment of DNA damage in blood cells of Sparus aurata exposed to benzo[a]pyrene using three distinct genotoxicity assays. Fresenius Environ. Bull. 18, 461-467.

Pascual, P., Pedrajas, J.R., Toribio, F., López-Barea, J., Peinado, J., 2003. Effect of food deprivation on oxidative stress biomarkers in fish (Sparus aurata). Chem.- Biol. Interact. 145, 191-199.

Reynaud, S., Deschaux, P., 2005. The effects of 3-methylcholanthrene on lymphocyte proliferation in the common carp (Cyprinus carpio L.). Toxicology $211,156-264$.

Risso-de Faverney, C., Devaux, A., Lafaurie, M., Girard, J.P., Baily, B., Rahmani, R., 2001. Cadmium induces apoptosis and genotoxicity in rainbow trou hepatocytes through generation of reactive oxygen species. Aquat. Toxicol. 53, 65-76.

Robinson, M.K., Rustum, R.R., Chambers, E.A., Rounds, J.D., Wilmore, D.W., Jacobs, D.O., 1997. Starvation enhances hepatic free radical release following endotoxemia. J. Surg. Res. 69, 325-335.
Sarasin, A., 2003. An overview of the mechanisms of mutagenesis and carcinogenesis. Mutat. Res. 544, 99-106.

Schiffmann, D. de Boni, U., 1991. Dislocation of chromatin elements in prophase induced by diethylbestrol: a novel mechanism by which micronuclei can arise. Mutat. Res. 246, 113-122.

Shaw, J.P., Large, A.T., Donkin, P., Evans, S.V., Staff, F.J., Livingstone, D.R., Chipman, J.K. Peters, L.D., 2004. Seasonal variation in cytochrome P450 immunopositive protein levels, lipid peroxidation and genetic toxicity in digestive gland of the mussel Mytilus edulis. Aquat. Toxicol. 67, 325-336.

Singh, N.P., McCoy, M.T., Tice, R.R., Schneider, E.L., 1988. A simple technique for quantitation of low levels of DNA damage in individual cells. Exp. Cell Res. 175 184-191.

Siu, W.H.L., Cao, J., Jack, R.W., Wu, R.S.S., Richardson, B.J., Xu, L., Lam, P.K.S., 2004 Application of the comet and micronucleus assays to the detection of B[a]P genotoxicity in haemocytes of the green-lipped mussel (Perna viridis). Aquat. Toxicol. 66, 381-392.

Smolders, R., Bervoets, L., Blust, R., 2004. In situ and laboratory bioassays to evaluate the impact of effluent discharges on receiving aquatic ecosystems. Environ. Pollut. 132, 231-243.

Soto-Reyes, E., del Razo, L.M., Valverde, M., Rojas, E., 2005. Role of the alkali labile sites, reactive oxygen species and antioxidants in DNA damage induced by methylated metabolites of inorganic arsenic. BioMetals 18, 493-506.

Spink, D.D., Katz, B.H., Hussain, M.M., Spink, B.C., Wu, S., Liu, N., Pause, R. Kaminsky, R.P., 2002. Induction of Cyp1A and CYP1B1 in T47-D human breast cancer cells by benzo[a]pyrene is diminished by arsenite. Drug Metab. Dispos. 30, 262-269.

Uchiyama, M., Mihara, M., 1978. Determination of malonaldehyde precursor in tissues by thiobarbituric acid test. Anal. Biochem. 86, 271-278.

Vakharia, D.D., Liu, N., Pause, R., Fasco, M., Bessette, E., Zhang, Q.-Y., Kaminsky, L.S. 2001. Polycyclic aromatic hydrocarbon/metal mixtures: effect con PAH induction of CYP1A1 in human HEPG2 cells. Drug Metab. Dispos. 29, 999-1006.

van der Oost, R., Beyer, J., Vermeulen, N.P.E., 2003. Fish bioaccumulation and biomarkers in environmental risk assessment: a review. Environ. Toxicol. Pharmacol. 13, 57-149.

van Kampen, E.J., Zijlstra, W.G., 1961. Standardization of hemoglobinometry. II The hemiglobincyanide method. Clin. Chim. Acta 6, 538-544.

Wirzinger, G., Weltje, L., Gercken, J., Sordyl, H., 2007. Genotoxic damage in fieldcollected three-spined sticklebacks (Gasterosteus aculeatus L.): a suitable biomonitoring tool? Mutat. Res. 628 19-30.

Yáñez, L., Borja-Aburto, H., Rojas, E., de la Fuente, H., González-Amaro, R., Gómez, H., Jongitud, A., Díaz-Barriga, F., 2004. DDT induces DNA damage in blood cells. Studies in vitro and in women chronically exposed to this insecticide. Environ. Res. 94, 18-24. 